\title{
Sonication-induced formation of size-controlled self-assemblies of amphiphilic Janus-type polymers as optical tumor-imaging agents.
}

\section{$\operatorname{AUTHOR(S):~}$}

Miki, Koji; Hashimoto, Hiroki; Inoue, Tatsuhiro;

Matsuoka, Hideki; Harada, Hiroshi; Hiraoka, Masahiro; Ohe, Kouichi

\section{CITATION:}

Miki, Koji ... [et al]. Sonication-induced formation of size-controlled self-assemblies of amphiphilic Janus-type polymers as optical tumor-imaging agents.. Small 2014, 10(15): 3119-3130

\section{ISSUE DATE:}

2014-04-14

URL:

http://hdl.handle.net/2433/200192

\section{RIGHT:}

This is the peer reviewed version of the following article: Miki, K., Hashimoto, H., Inoue, T., Matsuoka, H., Harada, H., Hiraoka, M. and Ohe, K. (2014), Sonication-Induced Formation of Size-Controlled Self-Assemblies of Amphiphilic JanusType Polymers as Optical Tumor-Imaging Agents. Small, 10:3119-3130, which has been published in final form at http://dx.doi.org/10.1002/smll.201400358. This article may be used for non-commercial purposes in accordance with Wiley Terms and Conditions for Self-Archiving.; This is not the published version. Please cite only the published version.; この論文は出版社版でありません。引用の際には出版社版をご確認ご利用ください。 
 \\ Submitted to

DOI: $10.1002 /$ smll.((please add manuscript number))

\section{Sonication-Induced Formation of Size-Controlled Self-Assemblies of Amphiphilic} Janus-Type Polymers as Optical Tumor-Imaging Agents

Koji Miki, * Hiroki Hashimoto, Tatsuhiro Inoue, Hideki Matsuoka, Hiroshi Harada, Masahiro Hiraoka, and Kouichi Ohe*

[*] Dr. K. Miki, H. Hashimoto, T. Inoue, Prof. K. Ohe Department of Energy and Hydrocarbon Chemistry, Graduate School of Engineering, Kyoto University, Nishikyo-ku, Kyoto 615-8510, Japan

E-mail: kojimiki@scl.kyoto-u.ac.jp,ohe@scl.kyoto-u.ac.jp

Prof. H. Matsuoka

Department of Polymer Chemistry,Graduate School of Engineering, Kyoto University, Nishikyo-ku, Kyoto 615-8510, Japan

Prof. H. Harada, Prof. M. Hiraoka Department of Radiation Oncology and Image-applied Therapy, Graduate School of Medicine, Kyoto University, 54 Shogoin Kawahara-cho, Sakyo-ku, Kyoto 606-8507, Japan

Supporting Information is available on the WWW under http://www.small-journal.com or from the author.

Keywords: Janus-type polymer, self-assembly, sonication, tumor imaging, size-control 


\section{Submitted to $S$ MICRO}

\section{Abstract}

In this study, amphiphilic Janus-type polymers were synthesized via ring-opening metathesis polymerization (ROMP), multiple vicinal diol formation, and grafting of poly(ethylene glycol) monomethyl ether (mPEG). These amphiphilic polymers formed self-assemblies, which were a mixture of micelles and multimicellar aggregates, in water. By choosing suitable Janus-type polymers and irradiating an aqueous solution of polymers using a sonicator, either small micelles or large multimicellar aggregates were obtained selectively. Hydrophobic substituents controlled the aggregation-disaggregation behavior, leading to the formation of metastable self-assemblies by sonication. The formation of self-assemblies with a uniform size was affected by ultrasonic frequency, rather than power. In vivo optical tumor imaging revealed that the large-size multimicellar aggregates persisting for a long time in blood circulation slowly accumulated in tumor tissues. In contrast, the tumor site was rapidly, clearly visualized using the small-size micelles. 


\section{stanallio}

\section{Introduction}

Nanostructures, especially spherical polymeric self-assemblies and their related aggregates, have recently attracted increased attention because of their huge potential to be used in medical applications, for examples as imaging agents or as carriers of drugs. ${ }^{[1-9]}$ Based on the phenomenon known as the enhanced permeability and retention (EPR) effect, ${ }^{[10]}$ via which nanometer-size polymeric self-assemblies accumulate passively and specifically in tumor tissues, research related to tumor diagnosis and therapy using self-assemblies has intensified. ${ }^{[1-9,11-23]}$ The control of the size of self-assemblies is one of the most important topics in this field, because it was recently reported that the size of polyion complex hollow vesicles (PICsomes) significantly affects their in vivo kinetics and tumor specificity for drug delivery. ${ }^{[24,25]}$ The size-dependent biodistribution of liposomes and the relationship between the size-dependent accumulation of liposomes and the local blood flow in tumor tissues have recently been investigated, using computed tomography, positron emission tomography, and fluorescence imaging. ${ }^{[26-29]}$ In contrast to these pioneering studies related to hollow nanocarriers, the effect of the size of solid self-assemblies on tumor targeting has not been intensively investigated.

Recently, we reported the synthesis of dye-conjugated amphiphilic polysaccharide analogues, which are dual-type polymers having a polypentose-mimicked backbone, via ringopening metathesis polymerization (ROMP) and dihydroxylation, and their application to high-contrast optical tumor imaging in vivo (Figure 1a). ${ }^{[30-34]}$ We successfully prepared various kinds of polymeric solid self-assemblies (diameter: $150-250 \mathrm{~nm}$ ) by introducing small alkyl groups, poly(methacrylate)s (PMAs), amino acids, and oligopeptides as hydrophobic side chains. However, the in vivo kinetics and tumor-imaging ability of small-size selfassemblies (diameter: $<100 \mathrm{~nm}$ ), which are considered to be more suitable for passive targeting by the EPR effect, have not been evaluated. 


\section{small}

Amphiphilic Janus-type polymers ${ }^{[35-39]}$ and dendrimers ${ }^{[40-43]}$ bearing two chemically distinct domains that do not enclose each other can form spherical self-assemblies (Figure 1b). In particular, the main chain of Janus-type polymers forms a cross-linked interface between a hydrophobic core and a hydrophilic shell, to prevent the disassembly of polymeric selfassemblies under dilute conditions. Furthermore, in contrast with dual-type polymers, the size of self-assemblies is controllable by changing the length of the side chains. ${ }^{[40,43]}$ Based on these properties, we investigated the formation of self-assemblies with various sizes using Janus-type polymers derived from polysaccharide analogues. Here, we report the aggregation-disaggregation behavior of polymeric micelles induced by sonication, and the evaluation of the application of self-assemblies of various sizes on optical tumor imaging.

(insert Figure 1 here)

\section{Results and Discussion}

\subsection{Synthesis of Janus-Type Amphiphilic Polymers}

Janus-type polymers 1 with hydrophobic alkyl chains and PMAs were successfully synthesized via ROMP ${ }^{[44,45]}$ and multi vicinal diol formation, followed by grafting of poly(ethylene glycol) monomethyl ether (mPEG) moieties (Figure 2). The ROMP of norbornadiene molecules bearing hydrophobic substituents gave the corresponding polymers with low polydispersity indices (PDI) in high yields $(82-91 \%$, PDI $=1.09 \sim 1.36)$. The polymer terminal was efficiently functionalized using vinyl ether as a quencher with a protected amino group (82-96\% capping efficiencies). ${ }^{[46,47]}$ Although we attempted to convert the alkenes on the polymer backbone using osmium-catalyzed dihydroxylation to obtain polyols, no reaction took place. Alkenes were converted to ethylene glycol moieties by sequential epoxidation with peracid and hydrolysis under acidic conditions (Figure S1). The 


\section{stanallio}

etherification of polyols with benzyl bromide bearing ethynyl groups, followed by CuIcatalyzed $[3+2]$ cyclization ${ }^{[48-50]}$ with an azide bearing an mPEG moiety afforded amphiphilic Janus-type polymers 1 . The moderate efficiencies $(50-80 \%)$ of $\mathrm{mPEG}$ grafting were attributed to the low conversion of hydroxy groups under etherification conditions $(20-50 \%$ of hydroxyl groups remained unreacted). The efficiency of etherification was not improved further by treatment with excess amounts of sodium hydride and benzyl bromide. ${ }^{1} \mathrm{H}$ NMR data confirmed that alkynes at the side chain terminus were fully converted under [3+2] cyclization conditions (Figure S2). It is noted that the $[3+2]$ cyclization did take place under modified conditions using copper (I) iodide and 1,8-diazabicyclo[5.4.0]undec-7-ene in $N, N$ dimethylformamide, instead of standard click conditions using copper (II) sulfate and sodium ascorbate.

(insert Figure 2 here)

\subsection{Sonication-Induced Formation of Size-Controlled Self-Assemblies of Amphiphilic Janus-Type Polymers}

All polymers 1 dissolved in water and formed spherical self-assemblies. In all cases with the exception of 1-PMA, both small-size (diameter: $20 \mathrm{~nm}$ ) and large-size (diameter: 100$300 \mathrm{~nm}$ ) self-assemblies were observed using dynamic light scattering (DLS) and transmission electron microscopy (TEM) (Table 1 and Figures 3a and 3c). The mean diameters of these aggregates changed neither for one week in phosphate buffered saline (PBS, pH 7.4), nor for one day in fetal bovine serum (10\% in PBS). TEM observation revealed that self-assemblies with small and large sizes seemd to be micellar and multimicellar aggregates, respectively. It is known that mild sonication usually accelerates the formation of well-dispersed polymeric self-assemblies in water. ${ }^{[51-54]}$ Next, we examined 


\section{stmall}

the sonication-induced formation of self-assemblies with a uniform size. After sonication (bath-type sonication, $150 \mathrm{~W}, 38 \mathrm{kHz}$ ) for $6 \mathrm{~h}$ of an aqueous solution of polymer $\mathbf{1 - \mathbf { C } _ { \mathbf { 1 4 } }}$ bearing long tetradecyl chains, multimicellar aggregates were gradually disassembled to form micelles, the spherical shapes of which were observed by TEM (Figure 3b), whereas their size distribution was measured by DLS (Figure 4a). Because the ${ }^{1} \mathrm{H}$ NMR spectrum of $\mathbf{1 - C _ { 1 4 }}$ did not change after sonication, polymers were not degraded under the sonication conditions (Figure S4). Polymer 1- $\mathbf{C}_{\mathbf{2} 2}$ bearing much longer alkyl chains also formed micelles with a diameter of $24 \mathrm{~nm}$ after sonication (Figure S5f and S7g). The size distribution of micelles with a uniform size did not change for $24 \mathrm{~h}$, but it gradually reverted to the original state observed before sonication (Figures 5a and 5b). In contrast, sonication of an aqueous solution of polymer 1-C $\mathbf{5}$ bearing shorter alkyl chains caused the aggregation of micelles leading to multimicellar aggregates (Figures $3 \mathrm{~d}$ and $4 \mathrm{~d}$ ). The size distribution of multimicellar aggregates did not change for at least $24 \mathrm{~h}$ (Figure $5 \mathrm{c}$ ). In the cases of $\mathbf{1 - \mathbf { C } _ { \mathbf { 8 } } \text { and }}$ 1-C $\mathbf{C}_{11}$, the alkyl lengths of which were between those of $\mathbf{1}-\mathbf{C}_{\mathbf{5}}$ and $\mathbf{1}-\mathbf{C}_{\mathbf{1 4}}$, the ratio of micelles to multimicellar aggregates gradually increased under ultrasound irradiation. However, both micelles and multimicellar aggregates were still observed even after sonication for $6 \mathrm{~h}$ (Figures $4 \mathrm{~b}$ and $4 \mathrm{c}$ ). Polymer 1-H bearing the shortest alkyl chains formed only large aggregates after sonication (Figures $\mathrm{S} 5 \mathrm{a}$ and $\mathrm{S} 7 \mathrm{a}$ ). Regarding polymers $\mathbf{1}-\mathbf{b C}_{\mathbf{8}}$ and $\mathbf{1}$-chol bearing branched and bulky alkyl groups, a similar sonication-induced aggregation was observed (Figures S5c, S5g, S7d, and S7h). Although the sonication-induced formation of supramolecular aggregates, such as gels ${ }^{[55-64]}$ and fibrils, ${ }^{[65-67]}$ caused by hydrogen bonding, $\pi-\pi$ interaction, and van der Waals interaction has been reported, there are few examples of the sonication-induced aggregation of micelles. It is difficult to clarify the driving force behind this aggregation; however, it is obvious that the hydrophobic substituents control the aggregation-disaggregation behavior, leading to the formation of metastable self-assemblies 


\section{Submitted to}

by sonication. This implies that a mixture of self-assemblies with small and large sizes is the most favorable state in water for the present amphiphilic Janus-type polymers. Polymer 1-PMA formed self-assemblies with diameters of $\sim 100 \mathrm{~nm}$ without sonication and the distribution of diameters did not change after sonication (Figure S9).

(insert Table 1 here)

(insert Figure 3 here)

(insert Figure 4 here)

(insert Figure 5 here)

The effects of the power and frequency of the sonication instrument as well as the ultrasonic exposure time were also investigated. The irradiation of an aqueous solution of 1-C $\mathbf{C}_{14}$ using another bath-type sonicator with a lower power and a similar frequency (100 W, $45 \mathrm{kHz}$ ) led to the formation of similar small micelles within $6 \mathrm{~h}$ (Figure 6b). Although no change in size distribution was observed by ultrasonic irradiation at higher frequency $(100 \mathrm{~W}$, $100 \mathrm{kHz})$, the irradiation at lower frequency $(100 \mathrm{~W}, 28 \mathrm{kHz})$ accelerated the change in size distribution, small micelles being formed within $3 \mathrm{~h}$ (Figures 6a and 6c). These results indicate that the frequency of ultrasound is the important factor for the ultrasound-induced formation of self-assemblies with a uniform size. It is known that ultrasonic irradiation at lower frequency creates large cavitation bubbles that generate stronger shear forces upon their collapse. Isozaki, Naota, Takaya, and coworkers recently reported that the rate of ultrasoundinduced self-assembly of metalated dipeptides increases with decreasing frequencies of 


\section{smallion}

ultrasound. ${ }^{[68]}$ Based on the relationship between the cavitation energy and the rate of selfassembly, it was pointed out that microcavitation caused by ultrasound irradiation is a key factor in self-assembly. Because a similar rate increment with decreasing frequencies was observed in our case, we suppose that the dynamic aggregation-disaggregation of micelles to form metastable aggregates might be similarly accelerated by the shear force induced at low frequency rather than the acoustic streaming induced at high frequency.

(insert Figure 6 here)

\subsection{Size-Dependent Tumor Accumulation and Blood Circulation of Self-Assemblies}

To evaluate the tumor targetability of polymeric self-assemblies as in vivo optical tumorimaging agents, we conjugated the near-infrared fluorescent dye, indocyanine green (ICG), to amphiphilic Janus-type polymers. After deprotection of the Ns groups of $\mathbf{1 - C} \mathbf{C}_{\mathbf{5}}, \mathbf{1}-\mathbf{C}_{\mathbf{1 4}}$, and 1-PMA, followed by transamidation using an activated ester bearing an ICG dye moiety, ICG-conjugated Janus-type polymers 2 were obtained (Table 2). To obtain highly fluorescent self-assemblies, it is important to place the ICG moieties in the hydrophobic environment, where hydrophobic dyes can generally emit stronger fluorescence than they can under hydrophilic polar conditions. In our previous study, we found that the choice of a suitable length of the side chains between the ICG moieties and the amphiphilic polymer backbone dramatically enhanced the fluorescence intensities of self-assemblies in vivo as well as in aqueous solution. Based on this finding, we precisely regulated the length of linkers connecting an ICG moiety with the main chain terminal to obtain highly emissive selfassemblies (Figure S3). In the case of alkyl-grafted polymers, the use of a $\omega$-amino acid, such as 8-aminooctanoic acid, as a linker improved the fluorescence intensities of their selfassemblies. In contrast, in the case of PMA-grafted polymers, the elongation of the linker length between an ICG moiety and the main chain led to a decrease in fluorescence intensity. 


\section{Submitted to}

These results showed that for alkyl-grafted polymers, the hydrophobic alkyl side chains form a densely packed hydrophobic domain that only an ICG moiety with a long linker could reach. Regarding the PMA-grafted polymer, an ICG moiety with a short linker reached a large hydrophobic core consisting of long PMA chains, but the elongation of its linker length resulted in the decrement of fluorescence intensity, probably due to aggregation-induced fluorescence quenching.

(insert Table 2 here)

The diameters of the self-assemblies of $\mathbf{2}-\mathbf{C}_{\mathbf{5}}, \mathbf{2}-\mathbf{C}_{\mathbf{1 4}}$, and $\mathbf{2 - P M A}$, the linker lengths of which were adjusted for high-contrast imaging were 130, 20, and $170 \mathrm{~nm}$, as measured by DLS, respectively. Because hydrophobic ICG moieties were placed in the hydrophobic cores, the diameters of the self-assemblies became larger compared with those formed from the corresponding polymers 1 without ICG moieties. Low critical aggregation concentration (cac) values, which were measured using static light scattering (SLS), indicate that polymeric self-assemblies do not disassemble under diluted conditions in aqueous solution. Before carrying out the optical imaging in vivo, the excitation wavelength $(710 \mathrm{~nm})$ and the detection wavelength $(820 \mathrm{~nm})$ were optimized by measuring fluorescence intensity of aqueous solutions of 2 (Figure S13).

Next, we performed a series of optical tumor-imaging experiments using self-assemblies with different sizes. We intravenously injected solutions of self-assemblies into tumorbearing nude mice (tumor site: right hind leg) and monitored their distribution using an optical in vivo imaging device. Optical imaging using polymers 2 led to high-contrast images of tumor tissues within $3 \mathrm{~h}$, although fluorescence from the liver was detected in the case of large self-assemblies consisting of 2-PMA (Figures 7a-c). It is noteworthy that the tumor site 


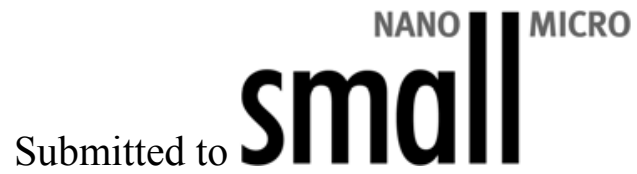

was clearly visualized within 10 min by the smallest self-assemblies of $\mathbf{2}-\mathbf{C}_{\mathbf{1 4}}$. The fluorescence intensity ratio (tumor/liver) showed that self-assemblies with a smaller size could accumulate in tumor tissues much more rapidly and efficiently (Figure 7d). The tumor specificity over time is improved by the continuous accumulation of self-assemblies in tumor tissues and their smooth clearance from the liver (Tables S1-S3). In the case of the selfassemblies with a diameter of $20 \mathrm{~nm}$, half of the amounts were cleared from the blood vessels $3 \mathrm{~h}$ from injection because of rapid accumulation in tumor tissues as well as rapid excretion through the liver and the spleen, resulting in efficient cutting off of the background fluorescence intensity (Figure 7e and see also the SI).

(insert Figure 7 here)

Kishimura, Kataoka, and coworkers recently reported that the tumor/liver ratio and the blood circulation of PICsomes with a diameter of $102 \mathrm{~nm}$ are better than those observed for a diameter of $38 \mathrm{~nm} \cdot{ }^{[25]}$ It was demonstrated that the polymer pharmacokinetics as well as the biodistribution could be controlled by the molecular weight and structure of the polymers. ${ }^{[69]}$ Therefore, we consider that the tumor specificity is profoundly affected not only by the size but also by the morphology of the self-assemblies. We suppose that larger hollow selfassemblies that persist for a long time in blood circulation can deform and pass through small pores in the blood vessel wall to accumulate in tumor tissues gradually by the EPR effect, resulting in a better tumor/liver ratio compared with smaller ones. In contrast, densely packed multimicellar aggregates composed of amphiphilic Janus-type polymers do not readily deform; therefore, smaller micelles could accumulate in tumor tissues more efficiently.

The optical imaging experiments of harvested major organs show that self-assemblies of 2-C $\mathbf{C}_{\mathbf{1 4}}$ with small sizes more efficiently accumulated at the tumor site (Figure $7 \mathrm{f}$ ). Although 


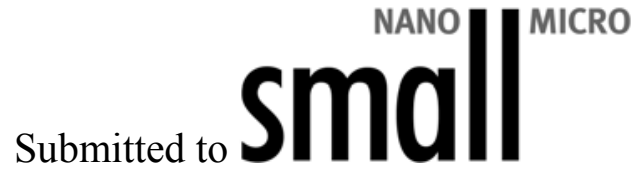

fluorescence intensities of $\mathbf{2}-\mathbf{C}_{\mathbf{1 4}}$ in tumor tissues were much stronger than those in normal tissues in optical imaging in vivo, those in the harvested tumor tissues were slightly stronger than those in the harvested liver. This might be caused by underestimation of fluorescence from normal tissues in the ventral cavity. Although further improvement is necessary for diagnostic purposes, these results suggest that self-assemblies with a diameter of $20 \mathrm{~nm}$, that can accumulate in tumor tissues rapidly and specifically and can be excreted from the blood vessels smoothly, are suitable for ultrarapid and high-contrast visualization of subcutaneous tumor tissues during endoscopy or surgery.

\section{Conclusion}

In summary, we achieved the facile synthesis of amphiphilic Janus-type polymers with terminal functionality, and demonstrated their application to ultrarapid optical tumor imaging. The amphiphilic Janus-type polymers dissolved in water and formed self-assemblies, which were a mixture of micelles and multimicellar aggregates. By irradiating an aqueous solution of polymers using a sonicator, self-assemblies with a uniform size were obtained. Hydrophobic substituents controlled the aggregation-disaggregation behavior, leading to the formation of either micelles or multimicellar aggregates. The large-size self-assemblies $(>100 \mathrm{~nm})$ circulated in the blood vessels for a long time and gradually accumulated in tumor tissues through the EPR effect. Conversely, optical imaging of tumor tissues using selfassemblies with a small size $(\sim 20 \mathrm{~nm})$ could be achieved within $10 \mathrm{~min}$ with high contrast. From the practical application perspective, it is necessary to shorten the sonication time and/or elongate the life time of small self-assemblies. We believe that the size-controllable self-assemblies will find advanced application as high-performance tumor-imaging agents.

\section{Experimental Section}




\section{sumestsmall}

Materials and Methods: Grubbs' 3rd catalyst was prepared from Grubbs' 2nd catalyst with 3-bromopyridine according to the reported procedure. ${ }^{[45]}$ Grubbs' 2 nd catalyst was purchased from Sigma-Aldrich (St. Louis, MO). 1,8-Diazabicyclo[5.4.0]undec-7-ene (DBU), $N, N$ dimethylformamide (DMF), piperidine, thiophenol, potassium carbonate $\left(\mathrm{K}_{2} \mathrm{CO}_{3}\right)$, and dimethylsulfoxide (DMSO) were purchased from nacalai tesque (Japan). 1-Ethyl-3-(3dimethylaminopropyl)carbodiimide hydrochloride $(\mathrm{EDC} \cdot \mathrm{HCl})$ was purchased from Tokyo Chemical Industry (TCI) Co., Ltd. (Japan). m-Chloroperbenzoic acid (mCPBA), acetic acid $(\mathrm{AcOH})$, sodium hydride $(\mathrm{NaH})$, and copper iodide $(\mathrm{CuI})$ were purchased from Wako Pure Chemicals Inc. (Japan). Ethyl acetate (EtOAc), chloroform $\left(\mathrm{CHCl}_{3}\right)$, dried tetrahydrofuran (THF) and dried dichloromethane $\left(\mathrm{CH}_{2} \mathrm{Cl}_{2}\right)$ were purchased from Sasaki Chemical Co., Ltd. (Japan). 1-Hydroxybenzotriazole (HOBt) was purchased from Watanabe Chemical Industry, Ltd. (Japan). DMF was distilled over $\mathrm{CaH}_{2}$ before use. Dialysis membrane, Spectra/Por 6 (molecular weight cut-off (MWCO): 3500), was purchased from Spectrum Laboratories Inc. (Rancho Dominguez, CA, USA). Silica gel (230-400 mesh) for column chromatography was purchased from Silicycle (Canada).

The synthetic procedures of monomers 3 (Figure 8) are summarized in the SI. The abbreviation MW(theor) means a theoretical molecular weight of polymers. Number-average molecular weight $\left(\mathrm{M}_{\mathrm{n}}\right)$ and polydispersity index (PDI) were determined by GPC (Shodex GPC-104, Showa Denko K. K., Japan) with polystyrene standards.

(insert Figure 8 here)

Synthesis of Amphiphilic Janus-Type Polymers 1: The amphiphilic Janus-type polymers were synthesized via ROMP and mPEG-grafting (Figure 9 and Table 3). 


\section{smallla}

(insert Figure 9 here)

(insert Table 3 here)

To a solution of ruthenium catalyst (Grubbs 3 rd catalyst, $18 \mathrm{mg}, 2.0 \times 10^{-2} \mathrm{mmol}$ ) in $\mathrm{CH}_{2} \mathrm{Cl}_{2}$ (2.0 mL) was added 3-H $\left(0.1 \mathrm{M}\right.$ in $\left.\mathrm{CH}_{2} \mathrm{Cl}_{2}, 2.0 \mathrm{~mL}, 0.20 \mathrm{mmol}\right)$ at room temperature. After stirring for $5 \mathrm{~min}$, the quencher $\left(0.2 \mathrm{M}\right.$ in $\left.\mathrm{CH}_{2} \mathrm{Cl}_{2}, 2.0 \mathrm{~mL}, 0.40 \mathrm{mmol}\right)$ was added to the solution. After stirring for $20 \mathrm{~min}$, organic solvent was removed under reduced pressure and the residue was subjected to GPC (eluent: $\mathrm{CHCl}_{3}$, flow rate: $3.8 \mathrm{~mL} / \mathrm{min}$ ) to afford $\mathbf{4 - H}$ (35 $\mathrm{mg}, 88 \%$ ) as a brown solid. Instead of GPC purification, reprecipitation with $\mathrm{CH}_{2} \mathrm{Cl}_{2} /$ hexane could be acceptable to purify polymers. ${ }^{1} \mathrm{H} \mathrm{NMR}\left(400 \mathrm{MHz}, \mathrm{CDCl}_{3}, \delta\right): 0.77-0.97(\mathrm{~m}, 30 \mathrm{H})$, $1.12-1.51(\mathrm{~m}, 67 \mathrm{H}), 1.80-2.11(\mathrm{~m}, 20 \mathrm{H}), 2.21-2.42(\mathrm{~m}, 5 \mathrm{H}), 2.43-2.57(\mathrm{~m}, 2 \mathrm{H}), 2.80-2.96(\mathrm{~m}$, 20H), 5.01-5.57 (m, 33H), 7.57-7.63 (m, 0.8H), 7.64-7.71 (m, 1.8H), 7.96-8.02 (m, 0.8H). The degree of polymerization of $4-\mathrm{H}$ was estimated at $\sim 10$ by measuring ${ }^{1} \mathrm{H} \mathrm{NMR}$ in $\mathrm{CD}_{2} \mathrm{Cl}_{2}$. The spectral data of other polymers $\mathbf{4}$ are summarized in the SI.

To a solution of polymer $4-\mathbf{H}\left(35 \mathrm{mg}, 1.8 \times 10^{-2} \mathrm{mmol}\right)$ in $\mathrm{CHCl}_{3}(3.0 \mathrm{~mL})$ was added $m \mathrm{CPBA}(69-75 \mathrm{w} \%, 0.16 \mathrm{~g}$, ca. $0.65 \mathrm{mmol})$ at $0{ }^{\circ} \mathrm{C}$. After stirring at room temperature for 16 h, a sat. $\mathrm{NaHCO}_{3}$ aqueous solution $(10 \mathrm{~mL})$ was added to the mixture. The aqueous layer was extracted with $\mathrm{CHCl}_{3}(10 \mathrm{~mL} \times 3)$. The combined organic layer was washed with a sat. $\mathrm{NaHCO}_{3}$ aqueous solution $(10 \mathrm{~mL} \times 3)$, dried over $\mathrm{MgSO}_{4}$, and concentrated in vacuo. The residue was subjected to $\mathrm{GPC}$ (eluent: $\mathrm{CHCl}_{3}$, flow rate: $3.8 \mathrm{~mL} / \mathrm{min}$ ) to afford the crude epoxide. To a solution of the epoxide in EtOAc $(2.0 \mathrm{~mL})$ were added water $(0.10 \mathrm{~g})$ and $\mathrm{AcOH}(70 \mathrm{mg})$ at room temperature. After stirring at $40{ }^{\circ} \mathrm{C}$ for $12 \mathrm{~h}$, the volatiles were removed under reduced pressure to afford polymer $\mathbf{5 - H}(32 \mathrm{mg}, 66 \%)$ as a brown solid. ${ }^{1} \mathrm{H}$ NMR (400 MHz, $\left.\mathrm{CDCl}_{3}, \delta\right): 0.75-0.98(\mathrm{~m}, 30 \mathrm{H}), 1.12-1.65(\mathrm{~m}, 81 \mathrm{H}), 1.70-2.43(\mathrm{~m}, 21 \mathrm{H})$, 


\section{stmall}

2.75-3.66 $(\mathrm{m}, 63 \mathrm{H}), 7.61-8.10(\mathrm{~m}, 3 \mathrm{H})$. It is confirmed by ${ }^{1} \mathrm{H}$ NMR measurement that the peaks of olefin protons of 4-H detected around 5.01-5.57 ppm completely disappeared under the present reaction conditions. The spectral data of other polymers $\mathbf{5}$ are summarized in the SI.

To a solution of polymer $\mathbf{5}-\mathbf{H}\left(32 \mathrm{mg}, 1.2 \times 10^{-2} \mathrm{mmol}\right)$ in THF $(3.0 \mathrm{~mL})$ was added $\mathrm{NaH}$ $(60 \mathrm{wt} \%$ in oil, $0.80 \mathrm{~g}, 2.0 \mathrm{mmol})$ at $0{ }^{\circ} \mathrm{C}$. After stirring at room temperature for $1 \mathrm{~h}$, to the solution was added a solution of 1-bromomethyl-4-(2-propyn-1-yloxy)benzene ${ }^{[70]}(0.23 \mathrm{~g}, 1.0$ mmol) in THF $(2.0 \mathrm{~mL})$. After stirring at $60{ }^{\circ} \mathrm{C}$ for $17 \mathrm{~h}$, the reaction mixture was cooled and water $(2.0 \mathrm{~mL})$ was added to the mixture. Organic solvent (THF) was removed under reduced pressure and the aqueous layer was extracted with $\mathrm{CHCl}_{3}(10 \mathrm{~mL} \times 3)$. The combined organic layer was washed with brine $(10 \mathrm{~mL} \times 3)$, dried over $\mathrm{MgSO}_{4}$, and concentrated in vacuo. The residue was subjected to $\mathrm{GPC}$ (eluent: $\mathrm{CHCl}_{3}$, flow rate: $3.8 \mathrm{~mL} / \mathrm{min}$ ) to afford $\mathbf{6}-\mathbf{H}(53 \mathrm{mg}$, $62 \%$ ) as a brown solid. ${ }^{1} \mathrm{H}$ NMR (400 $\left.\mathrm{MHz}, \mathrm{CDCl}_{3}, \delta\right): 0.79-0.93(\mathrm{~m}, 30 \mathrm{H}), 1.09-1.62$ (m, $102 \mathrm{H}), 1.80-2.09(\mathrm{~m}, 22 \mathrm{H}), 2.38-2.60(\mathrm{~m}, 32 \mathrm{H}), 2.72-3.65(\mathrm{~m}, 90 \mathrm{H}), 3.98-5.11(\mathrm{~m}, 136 \mathrm{H})$, 6.58-7.09 $(\mathrm{m}, 55 \mathrm{H}), 7.69-7.98(\mathrm{~m}, 2 \mathrm{H})$. The efficiency of benzylation was confirmed by comparing the integrated values of peaks of methyl protons $(\delta 0.8-0.95)$ and benzyl and propargyl protons $(\delta 4.0-5.1)$. Benzylation efficiencies for $\mathbf{6}-\mathbf{H}, \mathbf{6}-\mathbf{C}_{\mathbf{5}}, \mathbf{6}-\mathbf{C}_{\mathbf{8}}, \mathbf{6}-\mathbf{b} \mathbf{C}_{\mathbf{8}}, \mathbf{6}-\mathbf{C}_{\mathbf{1 1}}, \mathbf{6}-$ $\mathbf{C}_{14}$, and 6-C $\mathbf{C}_{22}$ were $60 \sim 80 \%$, and that for 6-PMA was $50 \sim 60 \%$. The spectral data of other polymers $\mathbf{6}$ are summarized in the SI.

To a solution of 6-H $\left(53 \mathrm{mg}, 7.4 \times 10^{-3} \mathrm{mmol}\right)$ and $\mathrm{mPEG}$ bearing an azide group ${ }^{[71]}(0.70$ g, $\left.0.35 \mathrm{mmol}, \mathrm{M}_{\mathrm{n}}=2000\right)$ in DMF $(5.0 \mathrm{~mL})$ were added $\mathrm{CuI}\left(4.4 \mathrm{mg}, 2.0 \times 10^{-2} \mathrm{mmol}\right)$ and DBU ( $\left.3.5 \mathrm{mg}, 2.0 \times 10^{-2} \mathrm{mmol}\right)$ at room temperature. After stirring at $50{ }^{\circ} \mathrm{C}$ for $18 \mathrm{~h}$, the mixture was dialyzed against water (Milli-Q) for one day by using Spectra/Por $6(\mathrm{MWCO}=$ 3500). 1-H $\left(0.17 \mathrm{~g}, 32 \%\right.$, theoretical molecular weight calculated: $\left.6.8 \times 10^{4}\right)$ was obtained as a white solid after lyophilization. ${ }^{1} \mathrm{H}$ NMR $\left(400 \mathrm{MHz}, \mathrm{CDCl}_{3}, \delta\right): 0.77-0.95(\mathrm{~m}, 30 \mathrm{H}), 1.12-$ 


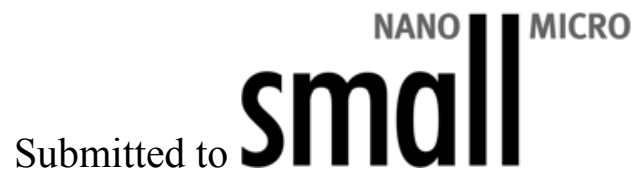

$1.65(\mathrm{~m}, 158 \mathrm{H}), 1.77-2.09(\mathrm{~m}, 43 \mathrm{H}), 3.25-4.07(\mathrm{~m}, 6220 \mathrm{H}), 4.38-4.71(\mathrm{~m}, 42 \mathrm{H}), 4.97-5.29(\mathrm{~m}$, $32 \mathrm{H}), 6.65-7.10(\mathrm{~m}, 33 \mathrm{H}), 7.69-8.00(\mathrm{~m}, 30 \mathrm{H})$. It is confirmed by ${ }^{1} \mathrm{H}$ NMR measurement that the peaks of terminal alkyne protons of 6-H detected around 2.38-2.60 ppm disappeared under the present reaction conditions. PEGylation efficiencies for all polymers 6 were $\sim 100 \%$. The spectral data of other polymers $\mathbf{1}$ are summarized in the SI.

Synthesis of Amphiphilic Janus-Type Polymers 2: The amphiphilic Janus-type polymers 2 bearing ICG moieties were synthesized via transamidation with an activated ester containing an ICG moiety (ICG-ATT) ${ }^{[34]}$ (Figure 10).

(Insert Figure 10 here)

Synthesis of Amphiphilic Janus-Type Polymers 2-PMA: To a solution of 1-PMA (85 mg, $\left.1.3 \times 10^{-3} \mathrm{mmol}\right)$ in DMF $(1.5 \mathrm{~mL})$ were added thiophenol $\left(3.0 \mu \mathrm{L}, 3.0 \times 10^{-2} \mathrm{mmol}\right)$ and $\mathrm{K}_{2} \mathrm{CO}_{3}$ (4.2 $\left.\mathrm{mg}, 3.0 \times 10^{-2} \mathrm{mmol}\right)$ at room temperature. After stirring for $24 \mathrm{~h}$, to the mixture was added a solution of ICG-ATT $\left(3.8 \mathrm{mg}, 6.0 \times 10^{-3} \mathrm{mmol}\right)$ in DMF $(1.0 \mathrm{~mL})$. After stirring for $15 \mathrm{~h}$, the resulting mixture was diluted with pure water $(2.0 \mathrm{~mL})$ and washed at least 10 times with $\mathrm{Et}_{2} \mathrm{O}$ until green color of the etheral solution disappeared (ICG-ATT is insoluble in water. We believe that the ICG moiety is attached covalently with polymer side chain. However, we do not exclude that small amount of ICG-ATT is contained in polymeric selfassemblies). The resulting aqueous solution was dialyzed against water (Milli-Q) for one day by using Spectra/Por $6(\mathrm{MWCO}=3500)$. The ICG-conjugated amphiphilic polymer 2-PMA was obtained as a green solid after lyophilization (82 $\mathrm{mg}, 1.3 \times 10^{-3} \mu \mathrm{mol}, 95 \%$, theoretical molecular weight calculated: $\left.6.5 \times 10^{4}\right) .{ }^{1} \mathrm{H} \mathrm{NMR}\left(400 \mathrm{MHz}, \mathrm{CDCl}_{3}, \delta\right): 0.63-2.17(\mathrm{~m}, 1760 \mathrm{H})$, 3.24-4.06 (m, 6240H), 4.29-4.61 (m, 47H), 5.00-5.28 (m, 38H), 6.61-7.09 (m, 72H), 7.707.98 (m, 24H). 


\section{stmall}

Synthesis of Amphiphilic Janus-Type Polymers 2-C $\boldsymbol{C}_{5}$ and $2-\boldsymbol{C}_{\mathbf{1 4}}$ : To a solution of $\mathbf{1 - C _ { 5 }}$ (250 $\left.\mathrm{mg}, 3.6 \times 10^{-3} \mathrm{mmol}\right)$ in DMF $(3.0 \mathrm{~mL})$ were added thiophenol $(61 \mu \mathrm{L}, 0.6 \mathrm{mmol})$ and $\mathrm{K}_{2} \mathrm{CO}_{3}$ (83 $\mathrm{mg}, 0.60 \mathrm{mmol}$ ) at room temperature. After stirring for $24 \mathrm{~h}$, the resulting mixture was diluted with pure water $(2.0 \mathrm{~mL})$ and the resulting aqueous solution was dialyzed against water (Milli-Q) for one day by using Spectra/Por $6(\mathrm{MWCO}=3500)$ to afford the deprotected polymer (238 mg, 95\%).

To a solution of a part of the deprotected polymer $(60 \mathrm{mg})$ in DMF $(3.0 \mathrm{~mL})$ were added 8(9H-fluoren-9-yl)methoxycarbonylamino)octanoic acid ${ }^{[72]}(7.6 \mathrm{mg}, 0.020 \mathrm{mmol}), \mathrm{EDC} \cdot \mathrm{HCl}$ (7.7 mg, $0.040 \mathrm{mmol})$, and $\mathrm{HOBt}(5.4 \mathrm{mg}, 0.040 \mathrm{mmol})$ at room temperature. After stirring the reaction mixture overnight, the resulting mixture was dialyzed by using Spectra/Por 6 (MWCO: 3500) against water (Milli-Q) for one day. The side chain-elongated amphiphilic polymer $(51 \mathrm{mg})$ was obtained after lyophilization.

The Fmoc group of the side chain-elongated polymer was removed by treating with piperidine in DMF $(5.0 \mathrm{~mL}, 20 \mathrm{wt} \%)$ at room temperature overnight. The reaction mixture was diluted with pure water $(3.0 \mathrm{~mL})$ and dialyzed by using Spectra/Por 6 (MWCO: 3500$)$ against water (Milli-Q) for one day. The deprotected polymer (35 mg) was obtained as an ocherous solid after lyophilization. To a solution of the polymer in DMSO $(2.0 \mathrm{~mL})$ was added a solution of ICG-ATT $(6.3 \mathrm{mg}, 0.010 \mathrm{mmol})$ in DMSO $(1.0 \mathrm{~mL})$ at room temperature. After stirring the mixture overnight, the reaction mixture was diluted with pure water $(2.0$ $\mathrm{mL}$ ). The aqueous solution was filtered and washed at least eight times with $\mathrm{Et}_{2} \mathrm{O}$ until green color of the etheral solution disappeared (Because ICG-ATT is insoluble in water, we believe that the ICG moieties are attached covalently with polymer side chain. However, we do not exclude the contamination of a small amount of ICG-ATT in polymeric self-assemblies). The volume of solvent was reduced by using lyophilization and the resulting aqueous solution was dialyzed by using Spectra/Por 6 (MWCO: 3500) against water (Milli-Q). The ICG- 


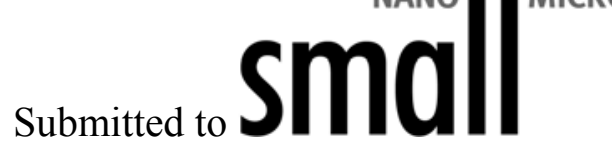

conjugated amphiphilic polymer $\mathbf{2}-\mathbf{C}_{\mathbf{5}}(31 \mathrm{mg}, 51 \%$, theoretical molecular weight calculated: $\left.7.0 \times 10^{4}\right)$ was obtained after lyophilization as a green solid. ${ }^{1} \mathrm{H} \mathrm{NMR}\left(400 \mathrm{MHz}, \mathrm{CDCl}_{3}, \delta\right)$ : 0.76-0.92 (m, 30H), 1.12-1.68 (m, 218H), 1.69-2.21 (m, 69H), 3.30-4.02 (m, 6185H), 4.52$4.63(\mathrm{~m}, 33 \mathrm{H}), 4.99-5.18(\mathrm{~m}, 30 \mathrm{H}), 6.55-7.01(\mathrm{~m}, 53 \mathrm{H}), 7.69-7.91(\mathrm{~m}, 23 \mathrm{H})$.

2-C $\mathbf{C}_{\mathbf{1 4}}$ was similarly synthesized from $\mathbf{1 - C _ { 1 4 }}$. 2-C $\mathbf{1 4}$ (a green solid, 84\%, theoretical molecular weight calculated: $\left.7.1 \times 10^{4}\right):{ }^{1} \mathrm{H}$ NMR (400 $\left.\mathrm{MHz}, \mathrm{CDCl}_{3}, \delta\right): 0.76-0.93(\mathrm{~m}, 30 \mathrm{H})$, 1.08-1.72 (m, 237H), 1.74-2.16 (m, 106H), 3.34-3.97 (m, 5492H), 4.33-4.64 (m, 39H), 5.03$5.24(\mathrm{~m}, 35 \mathrm{H}), 6.52-7.12(\mathrm{~m}, 77 \mathrm{H}), 7.69-7.91(\mathrm{~m}, 24 \mathrm{H})$.

Preparation and Characterization of Self-Assemblies: Amphiphilic Janus-type polymers 1 and 2 were dissolved in water (Milli-Q, $5 \mathrm{mg} / \mathrm{mL}$ ) and stored at room temperature for $30 \mathrm{~min}$ in dark. The resulting solution was filtered by syringe filter $(0.45 \mu \mathrm{m}$ pore size, PVDF filter membrane, Whatman, Florham Park, NJ). The measurements of properties of self-assemblies were carried out as soon as possible after preparation.

Sonication for $6 \mathrm{~h}$ or $12 \mathrm{~h}$ with bath-type sonicators ( $150 \mathrm{~W}, 38 \mathrm{kHz}$, USK-3, As One Corp., Osaka, Japan or $100 \mathrm{~W}, 28,45$, or $100 \mathrm{kHz}$, VS-100III, As One Corp., Osaka, Japan) was employed to obtain an aqueous solution of polymeric self-assemblies. The average temperature in the bath was ca. $40{ }^{\circ} \mathrm{C}$. For $\mathbf{1 - H}, \mathbf{1 - C _ { 5 }}, \mathbf{2}-\mathbf{C}_{\mathbf{5}}, \mathbf{1}-\mathbf{C}_{\mathbf{1 4}}, \mathbf{2}-\mathbf{C}_{\mathbf{1 4}}$, and 1-chol, it took

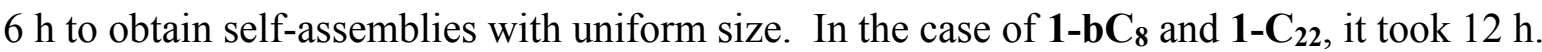

Characterization of Self-Assemblies by TEM Image Analysis: Transmission electron microscopy (TEM, Model H-9000NAR, Power Supply 200 V, 60 Hz, 15 kVA, Single Phase, Hitachi, Ltd., Tokyo, Japan) was used to visualize the morphology of dried self-assemblies. Samples were dropped onto a TEM copper grid covered with a carbon film (200 mesh, Nisshin EM, Japan) and dried for $3 \mathrm{~h}$. The distribution of diameters was determined by using TEM images of at least one hundred of self-assemblies. 


\section{smallion}

Characterization of Size Distribution Using DLS: Dynamic light scattering (DLS) was measured on FPAR-1000 (Otsuka Electronics Co, Ltd., Japan) at $20{ }^{\circ} \mathrm{C}$. The sample solutions were diluted in water (Milli-Q) and filtered prior to analysis (syringe filter, $0.45 \mu \mathrm{m}$ pore size, PVDF filter membrane, Whatman, Florham Park, NJ). The concentrations of the analyzed sample solutions were $0.05 \mathrm{~g} / \mathrm{L}$ (all polymers formed self-assemblies in this concentration). The measurements were performed at scattering angles of $90^{\circ}$ at $25^{\circ} \mathrm{C}$.

Measurement of Critical Aggregation Concentration (cac): The cac values of the dyecontaining polymers were determined using static light scattering (SLS, SLS-6000, Otsuka Electronics Co Ltd., Japan). ${ }^{[73]}$ The aqueous sample solutions of polymers in several concentrations were filtered prior to analysis (syringe filter, $0.45 \mu \mathrm{m}$ pore size, PVDF filter membrane, Whatman, Florham Park, NJ). A He-Ne laser (wavelength: $632.8 \mathrm{~nm}$ ) was used for the measurement. SLS measurements were carried out in a concentration range from 1.0 to $1.0 \times 10^{-6} \mathrm{~g} / \mathrm{L}$ at the detection angle, $90^{\circ}$. The measurements were performed at $25{ }^{\circ} \mathrm{C}$. Two independent measurements of static light intensity were taken at each concentration, and the reported cac values were averaged. The intensities of the scattering light over the incident light $\left(\mathrm{I}_{\mathrm{s}} / \mathrm{I}_{0}\right)$ were plotted against $\log \mathrm{C}(\mathrm{C}$ : polymer concentration $(\mathrm{g} / \mathrm{L}))$, and the cac values were determined at the point where $\mathrm{I}_{\mathrm{s}} / \mathrm{I}_{0}$ changed from a constant to a larger value.

Imaging Experiments In Vivo: For the current study, the human cervical epithelial adenocarcinoma cell line (HeLa) was purchased from American Type Culture Collection. Cells were cultured in 10\% FBS-Dulbecco's modified Eagle's medium and cultured in a wellhumidified incubator with $5 \% \mathrm{CO}_{2}$ and $95 \%$ air at $37^{\circ} \mathrm{C}$. The suspension of HeLa cells $(2 \times$ $10^{6}$ ) was subcutaneously inoculated into the right hind leg of 6-week-old nude mice (BALB/c nu/nu mice, SHIMIZU Laboratory Supplies Co. Ltd., Kyoto, Japan). Solutions of polymers 2- $\mathbf{C}_{\mathbf{5}}$ and $\mathbf{2}-\mathbf{C}_{14}$ in water (Milli-Q, $5 \mathrm{mg} / \mathrm{mL}$ ) as fluorescent probes were prepared, filtered (0.45 $\mu \mathrm{m}$ pore size, PVDF filter membrane, Whatman, Florham Park, NJ), sonicated for $6 \mathrm{~h}$ 


\section{stmallio}

and kept in dark at room temperature before injection. A solution of polymer 2-PMA in water (Milli-Q, $5 \mathrm{mg} / \mathrm{mL}$ ) was prepared, filtered and kept in dark at room temperature. Before injection, the size-distribution of all samples were measured by DLS. Each solution of fluorescent probes $(100 \mu \mathrm{L})$ was intravenously injected in each experiment within $6 \mathrm{~h}$ after preparation. Optical imaging experiments to detect the distribution of the fluorescent probes in tumor-bearing mice were carried out with an IVIS-200 in vivo imaging device (Xenogen, Alameda, CA, USA, excitation wavelength: $\lambda_{\mathrm{exc}}=710 \mathrm{~nm}$, detected wavelength: $\lambda_{\mathrm{em}}=820$ nm. Exposure time $=1 \mathrm{sec})$. During the imaging, the mice were anesthetized with $2.5 \%$ isoflurane gas in the oxygen flow $(1.5 \mathrm{~L} / \mathrm{min})$. Images were analyzed using Living Image 2.50-Igor Pro 4.09 software (Xenogen), according to the manufacturer's instructions. In all imaging experiments, the fluorescent probe in the same batch was injected to at least two mice and one set of experiment was repeated at least twice to confirm reproducibility, and representative images are shown. In order to emphasize the areas where imaging probes specifically accumulated, we set a threshold and represent intense fluorescence above it. All of our animal experiments were approved by the Animal Research Committee of Kyoto University and carried out in accordance with its guidelines.

Blood Half-Life Times of Polymeric Self-Assemblies: We measured blood half-life times of self-assemblies of polymers 2 . The experimental procedures as follows; Immuno deficient nude mice were intravenously injected with each imaging probe. Just, $3 \mathrm{~h}, 6 \mathrm{~h}$, and $24 \mathrm{~h}$ after the administration, $5 \mu \mathrm{L}$ of blood were harvested from tail vein and directly subjected to optical imaging device (IVIS-200) to quantify blood concentration of the probes, polymers 2 and indocyanine green dye (control: Almost all of dye was excreted within 30 min). Relative blood concentration was calculated by dividing the fluorescent intensity in each time point by that in the initial timepoint. 


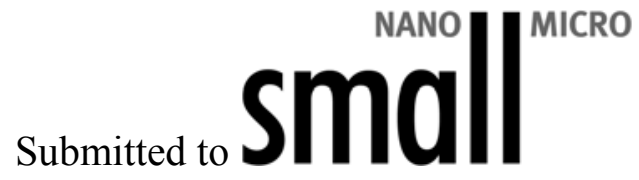

Ex Vivo Experiments: One day after injection, mice were sacrificed and the tumors as well as the major organs were harvested for ex vivo imaging (Figure S15). Before imaging, the organs were washed with phosphate buffered saline $(\mathrm{pH}=7.4)$. Optical imaging experiments to detect the distribution of the fluorescent probes in the major organs were carried out with IVIS-200 (excitation wavelength: $\lambda_{\mathrm{exc}}=710 \mathrm{~nm}$, detected wavelength: $\lambda_{\mathrm{em}}=820 \mathrm{~nm}$ ). In all imaging experiments, the fluorescent probe in the same batch was injected to at least two mice and one set of experiment was repeated at least twice to confirm reproducibility, and representative images are shown. All of our animal experiments were approved by the Animal Research Committee of Kyoto University and carried out in accordance with its guidelines.

\section{Acknowledgements}

This work is supported by Modality Xn program of Kyoto University/Canon joint research project-Innovative Techno-Hub for Integrated Medical Bio-imaging from MEXT Budget for the Promotion of Science and Technology, a Grant-in-Aid for Scientific Research on Innovative Areas "New Polymeric Materials Based on Element-Blocks (No. 2401)" (25102523) of The Ministry of Education, Culture, Sports, Science, and Technology, Japan, and Funding Program for Next Generation World-Leading Researchers (NEXT Program), Japan. K.M. thanks Takeda Science Foundation for financial support. We acknowledge Professor Takeshi Abe and Dr. Kohei Miyazaki in Kyoto University for TEM measurements, and Ms. Akiyo Morinibu in Kyoto University for technical assistance in imaging experiments in vivo.

[1] Nanomaterials for the Life Sciences, Vol. 10: Polymeric Nanomaterials, (Ed: C. S. S. R. Kumar), WILEY-VCH, Weinheim, 2011. 
[2] J. Y. Cherng, T. Y. Hou, M. F. Shih, H. Talsma, W. E. Hennink, Int. J. Pharm. 2013, $450,145$.

[3] A. Yousefi, G. Storm, R. Schiffelers, E. Mastrobattista, J. Control. Release 2013, 170, 209.

[4] A. Vollrath, S. Schubert, U. S. Schubert, J. Mater. Chem. B 2013, 1, 1994.

[5] T. Krasia-Christoforou, T. K. Georgiou, J. Mater. Chem. B 2013, 1, 3002.

[6] N. R. B. Boase, I. Blakey, K. J. Thurecht, Polym. Chem. 2012, 3, 1384.

[7] M. Ding, J. Li, H. Tan, Q. Fu, Soft Matter 2012, 8, 5414.

[8] G. Feng, D. Ding, B. Liu, Nanoscale 2012, 4, 6150.

[9] A. L. Petersen, A. E. Hansen, A. Gabizon, T. L. Andresen, Adv. Drug Deliver. Rev. 2012, 64, 1417.

[10] Y. Matsumura, H. Maeda, Cancer Res. 1986, 46, 6387.

[11] M. Yokoyama, J. Exp. Clin. Med. 2011, 3, 151.

[12] H. Cabral, K. Kataoka, Sci. Technol. Adv. Mater. 2010, 11, 014109.

[13] D. B. Pike, H. Ghandehari, Adv. Drug Deliver. Rev. 2010, 62, 167.

[14] A. S. Mikhail, C. Allen, J. Control. Release 2009, 138, 214.

[15] E. Segal, R. Satchi-Fainaro, Adv. Drug Deliver. Rev. 2009, 61, 1159.

[16] Y. Matsumura, K. Kataoka, Cancer Sci. 2009, 100, 572.

[17] B. E. Rolfe, I. Blakey, O. Squires, H. Peng, N. R. B. Boase, C. Alexander, P. G. Parsons, G. M. Boyle, A. K. Whittaker, K. J. Thurecht, J. Am. Chem. Soc. DOI: 10.1021/ja410351h.

_[18] S. Kunjachan, R. Pola, F. Gremse, B. Theek, J. Ehling, D. Moeckel, B. HermannsSachweh, M. Pechar, K. Ulbrich, W. E. Hennink, G. Storm, W. Lederle, F. Liessling, T. Lammers, Nano Lett. DOI: 10.1021/n1404391r.

_[19] P. Yang, D. Li, S. Jin, J. Ding, J. Guo, W. Shi, C. Wang, Biomaterials 2014, 34, 2079.

[20] X. Jiang, H. Xin, Q. Ren, J. Gu, L. Zhu, F. Du, C. Feng, Y. Xie, X. Sha, X. Fang, Biomaterials 2014, 35, 518.

[21] K. S. Kim, W. Park, J. Hu, Y. H. Bae, K. Na, Biomaterials 2014, 35, 337. 
[22] D. Ding, J. Liu, G. Feng, K. Li, Y. Hu, B. Liu, Small 2013, 9, 3093.

[23] H. Koo, K. H. Min, S. C. Lee, J. H. Park, K. Park, K. Choi, I. C. Kwon, K. Kim, J. Control. Release 2013, 172, 823.

[24] H. Cabral, Y. Matsumoto, K. Mizuno, Q. Chen, M. Murakami, M. Kimura, Y. Terada, M. R. Kano, K. Miyazono, M. Uesaka, N. Nishiyama, K. Kataoka, Nat. Nanotechnol. 2011, 6, 815 .

[25] Y. Anraku, A. Kishimura, A. Kobayashi, M. Oda, K. Kataoka, Chem. Commun. 2011, 47,6054

[26] R. Toy, E. Hayden, A. Camann, Z. Berman, P. Vicente, E. Tran, J. Meyers, J. Pansky, P. M. Peiris, H. Wu, A. Exner, D. Wilson, K. B. Ghaghada, E. Karathanasis, ACS Nano 2013, 7, 3118.

[27] S. Hirsjärvi, L. Sancey, S. Dufort, C. Belloche, C. Vanpouille-Box, E. Garcion, J.-L. Coll, F. Hindré, Int. J. Pharm. 2013, 453, 594.

[28] R. P. Brinkhuis, K. Stojanov, P. Laverman, J. Eilander, I. S. Zuhorn, F. P. J. T. Rutjes, J. C. M. van Hest, Bioconjugate Chem. 2012, 23, 958.

_[29] H. Wang, S. Wang, H. Su, K.-J. Chen, A. L. Armijo, W.- Y. Lin, Y. Wang, J. Sun, K.i. Kamei, J. Czernin, C. G. Radu, H.-R. Tseng, Angew. Chem. Int. Ed. 2009, 48, 4344.

[30] K. Miki, K. Nakano, H. Matsuoka, C. J. Yeom, H. Harada, M. Hiraoka, K. Ohe, Bull. Chem. Soc. Jpn. 2012, 85, 1277.

[31] K. Miki, A. Kimura, K. Oride, Y. Kuramochi, H. Matsuoka, H. Harada, M. Hiraoka, K. Ohe, Angew. Chem. Int. Ed. 2011, 50, 6567.

[32] K. Miki, K. Oride, A. Kimura, Y. Kuramochi, H. Matsuoka, H. Harada, M. Hiraoka, K. Ohe, Small 2011, 7, 3536.

_[33] K. Miki, K. Oride, S. Inoue, Y. Kuramochi, R. R. Nayak, H. Matsuoka, H. Harada, M. Hiraoka, K. Ohe, Biomaterials 2010, 31, 934.

[34] K. Miki, Y. Kuramochi, K. Oride, S. Inoue, H. Harada, M. Hiraoka, K. Ohe, Bioconjugate Chem. 2009, 20, 511.

[35] A. Walther, A. H. E. Müller, Chem. Rev. 2013, 113, 5194. 
 \\ sumanimates Small}

[36] Y. Chen, Macromolecules 2012, 45, 2619.

[37] Y. Li, E. Themistou, J. Zou, B. P. Das, M. Tsianou, C. Cheng, ACS Macro Lett. 2012, 1,52 .

[38] Y. Li, J. Zou, B. P. Das, M. Tsianou, C. Cheng, Macromolecules 2012, 45, 4623.

[39] D. Zehm, A. Laschewsky, M. Gradzielski, S. Prévost, H. Liang, J. P. Rabe, R. Schweins, J. Gummel, Langmuir 2010, 26, 3145.

[40] V. Percec, P. Leowanawat, H.-J. Sun, O. Kulikov, C. D. Nusbaum, T. M. Tran, A. Bertin, D. A. Wilson, M. Peterca, S. Zhang, N. P. Kamat, K. Vargo, D. Moock, E. D. Johnston, D. A. Hammer, D. J. Pochan, Y. Chen, Y. M. Chabre, T. C. Shiao, M. Bergeron-Brlek, S. André, R. Roy, H.-J. Gabius, P. A. Heiney, J. Am. Chem. Soc. 2013, 135, 9055 .

[41] Y. Liu, C. Yu, H. Jin, B. Jiang, X. Zhu, Y. Zhou, Z. Lu, D. Yan, J. Am. Chem. Soc. 2013, 135, 4765 .

[42] L. Sun, X. Ma, C.-M. Dong, B. Zhu, X. Zhu, Biomacromolecules 2012, 13, 3581.

[43] M. Peterca, V. Percec, P. Leowanawat, A. Bertin, J. Am. Chem. Soc. 2011, 133, 20507.

[44] T. M. Trnka, R. H. Grubbs, Acc. Chem Res. 2001, 34, 18.

[45] T.-L. Choi, R. H. Grubbs, Angew. Chem. Int. Ed. 2003, 42, 1743.

[46] K. Nomura, M. M. Abdellatif, Polymer 2010, 51, 1861.

[47] S. Hilf, A. F. M. Kilbinger, Nat. Chem. 2009, 1, 537.

[48] P. Thirumurugan, D. Matosiuk, K. Jozwiak, Chem. Rev. 2013, 113, 4905.

[49] R. K. Iha, K. L. Wooley, A. M. Nyström, D. J. Burke, M. J. Kade, C. J. Hawker, Chem. Rev. 2009, 109, 5620.

[50] F. Amblard, J. H. Cho, R. F. Schinazi, Chem. Rev. 2009, 109, 4207.

[51] H. K. S. Souza, J. M. Campina, A. M. M. Souza, F. Silva, M. P. Goncalves, Food Hydrocolloids 2013, 31, 227.

[52] K. Nakabayashi, M. Kojima, S. Inagi, Y. Hirai, M. Atobe, ACS Macro Lett. 2013, 2, 482.

[53] R. H. Fang, S. Aryal, C.-M. J. Hu, L. Zhang, Langmuir 2010, 26, 16958. 
[54] M. Yokoyama, A. Satoh, Y. Sakurai, T. Okano, Y. Matsumura, T. Kakizoe, K. Kataoka, J. Contolled Release 1998, 55, 219.

[55] J. Zhang, C.-Y. Su, Coord. Chem. Rev. 2013, 257, 1373.

[56] K. Liu, L. Meng, S. Mo, M. Zhang, Y. Mao, X. Cao, C. Huang, T. Yi, J. Mater. Chem. C 2013, 1, 1753.

[57] M. Zhang, L. Meng, X. Cao, M. Jiang, T. Yi, Soft Matter 2012, 8, 4494.

[58] C. Deng, R. fang, Y. Guan, J. Jiang, C. Lin, L. Wang, Chem. Commun. 2012, 48, 7973.

[59] N. Komiya, T. Muraoka, M. Iida, M. Miyanaga, K. Takahashi, T. Naota, J. Am. Chem. Soc. 2011, 133, 16054.

[60] C. Dou, D. Li, H. Gao, C. Wang, H. Zhang, Y. Wang, Langmuir 2010, 26, 2113.

[61] Y. He, Z. Bian, C. Kang, R. Jin, L. Gao, New J. Chem. 2009, 33, 2073.

[62] Z. Xie, A. Zhang, L. Ye, Z.-g. Feng, Soft Matter 2009, 5, 1474.

_[63] K. Isozaki, H. Takaya, T. Naota, Angew. Chem. Int. Ed. 2007, 46, 2855.

[64] T. Naota, H. Koori, J. Am. Chem. Soc. 2005, 127, 9324.

[65] P. B. Stathopulos, G. A. Scholz, Y.-M. Hwang, J. A. O. Rumfeldt, J. R. Lepock, E. M. Meiering, Protein Sci. 2004, 13, 3017.

[66] Y. J. Lee, R. Savtchenko, V. G. Ostapchenko, N. Makarava, I. V. Baskakov, PLos One 2011, 6, e20244.

_[67] Y. Yoshimura, Y. Lin, H. Yagi, Y.-H. Lee, H. Kitayama, K. Sakurai, M. So, H. Ogi, H. Naiki, Y. Goto, Proc. Natl. Acad. Sci. USA 2012, 109, 14446.

[68] K. Isozaki, Y. Haga, K. Ogata, T. Naota, H. Takaya, Dalton Trans. 2013, 42, 15953.

[69] M. E. Fox, F. C. Szoka, J. M. J. Fréchet, Acc. Chem. Res. 2009, 42, 1141.

[70] S. Binauld, D. Damiron, T. Hamaide, J.-P. Pascault, E. Fleury, E. Drockenmuller, Chem. Commun. 2008, 44, 4138.

[71] N. Mejías, R. Pleixats, A. Shafir, M. Medio-Simón, G. Asensio, Eur. J. Org. Chem. 2010, 5090 . 


\section{Submitted to

[72] C. Galoppini, S. Meini, M. Tancredi, A. Di Fenza, A. Triolo, L. Quartara, C. A. Maggi,

F. Formaggio, C. Toniolo , S. Mazzucco, A. Papini, P. Rovero, J. Med. Chem. 1999, 42,409 .

[73] A. Ghosh, S.-i. Yusa, H. Matsuoka, Y. Saruwatari, Langmuir 2011, 27, 9237.

Received: ((will be filled in by the editorial staff))

Revised: ((will be filled in by the editorial staff))

Published online on ((will be filled in by the editorial staff $)$ ) 


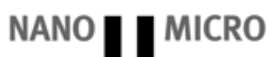 \\ sumumassmall}

(a) Previous work

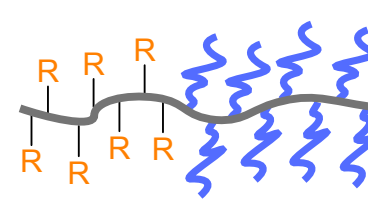

dual-type polymers

self-

assembled
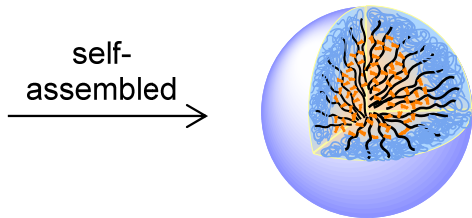

spherical self-assemblies

$($ diameter $=150-250 \mathrm{~nm})$

(b) This work

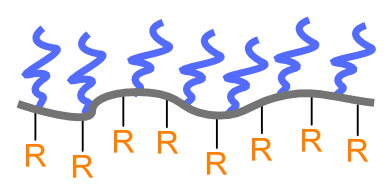

Janus-type polymers

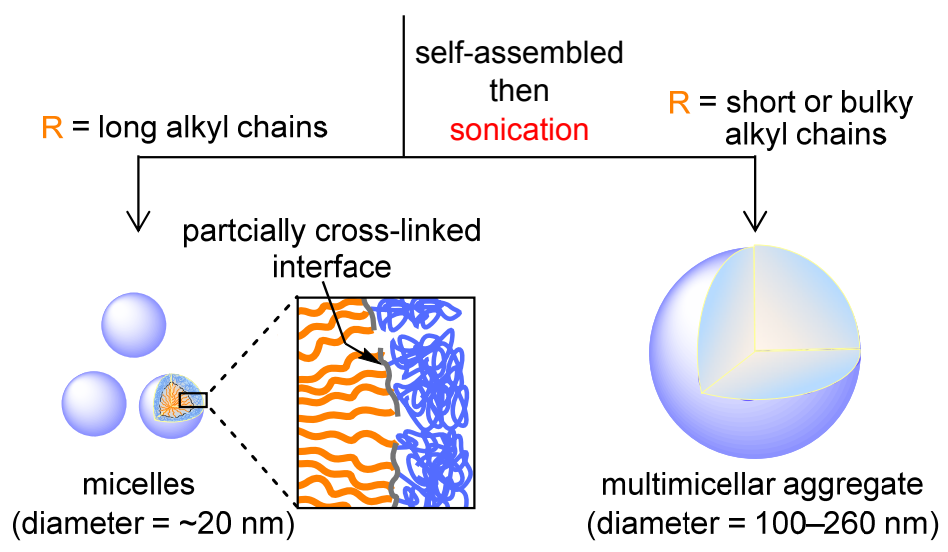

Figure 1. Spherical self-assemblies consisting of (a) dual-type and (b) Janus-type polymers. Orange and blue chains indicate hydrophobic and hydrophilic grafts, respectively. 
subminiced small

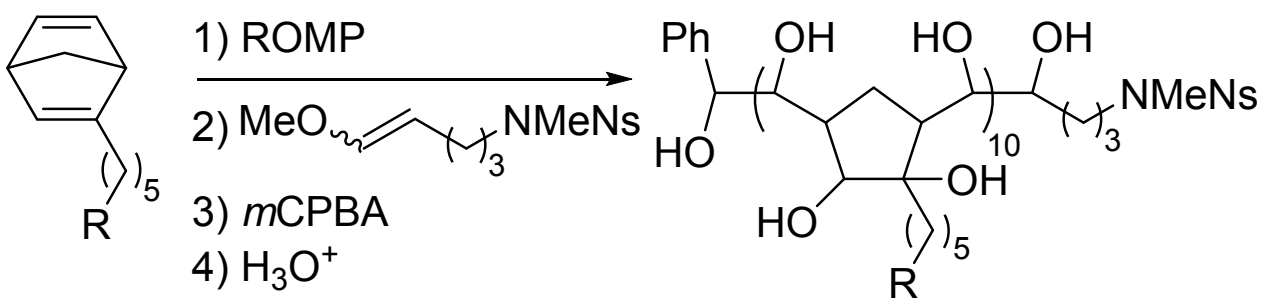

1) $\mathrm{NaH}$<smiles>C#CCOc1ccc(CBr)cc1</smiles>

2) Cul, DBU<smiles></smiles>

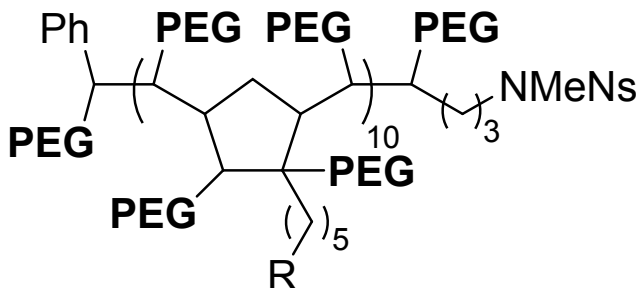

Janus-type polymers 1

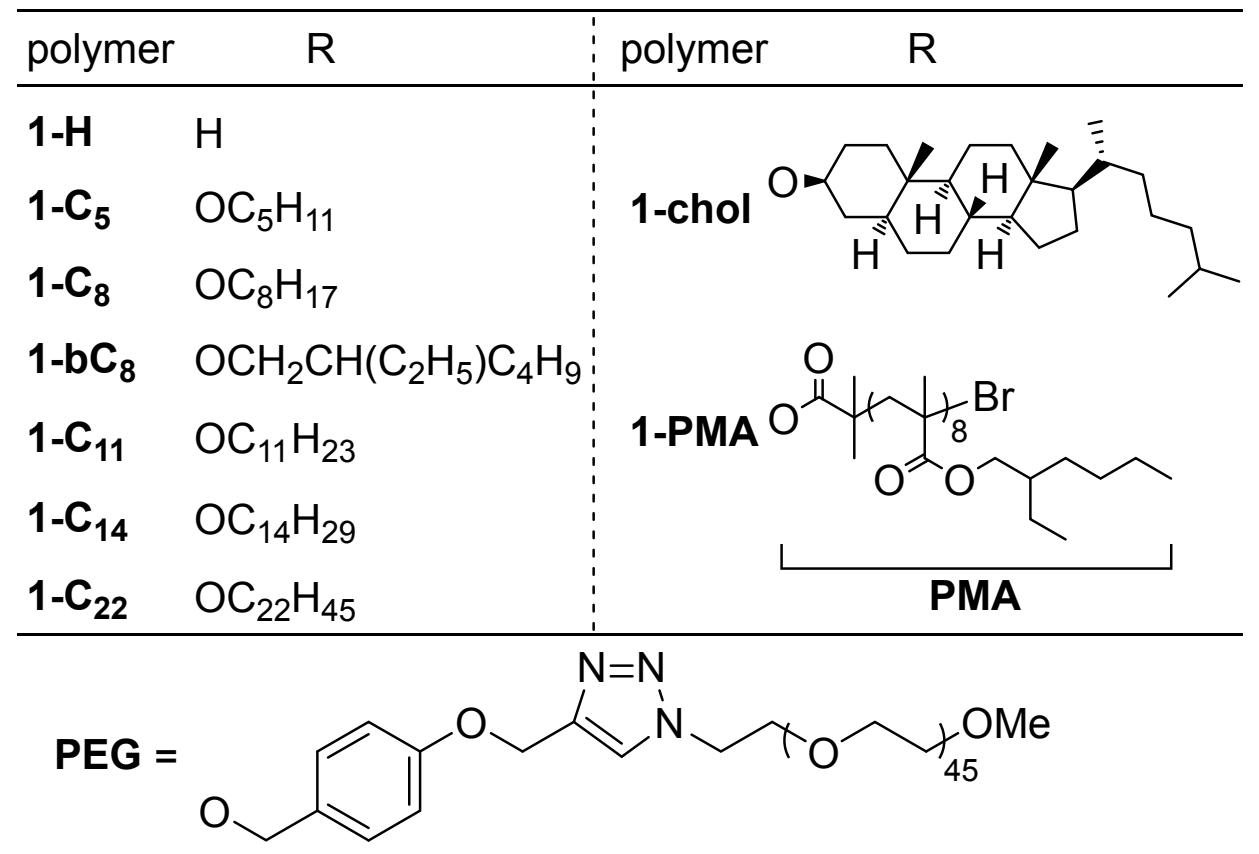

Figure 2. Synthesis of amphiphilic Janus-type polymers 1. Ns $=$ 2-nitrobenzenesulfonyl, $m \mathrm{CPBA}=m$-chloroperbenzoic acid, $\mathrm{DBU}=1,8$-diazabicyclo[5.4.0]undec-7-ene. Benzylation efficiency: $60-80 \%$ (1-H, 1-C $\mathbf{5}, \mathbf{1}-\mathbf{C}_{\mathbf{8}}, \mathbf{1 - b C _ { 8 }}, \mathbf{1}-\mathbf{C}_{\mathbf{1 1}}, \mathbf{1 - C _ { 1 4 }}, \mathbf{1 - C _ { 2 2 }}$, and 1-chol) and 50-60\% (1PMA). PEGylation efficiency: $\sim 100 \%$ in all cases. 
struminats small ${ }^{\text {mano }}$

(a)

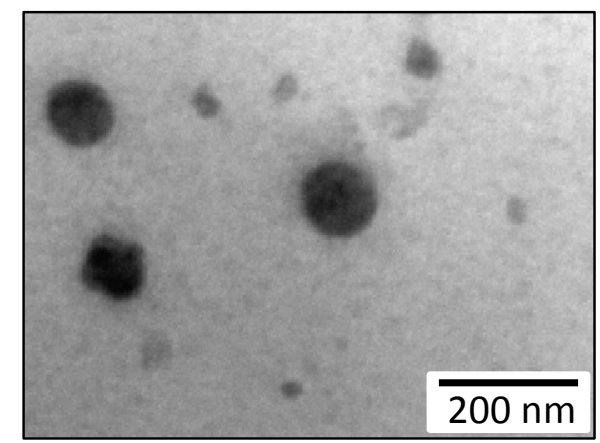

(c)

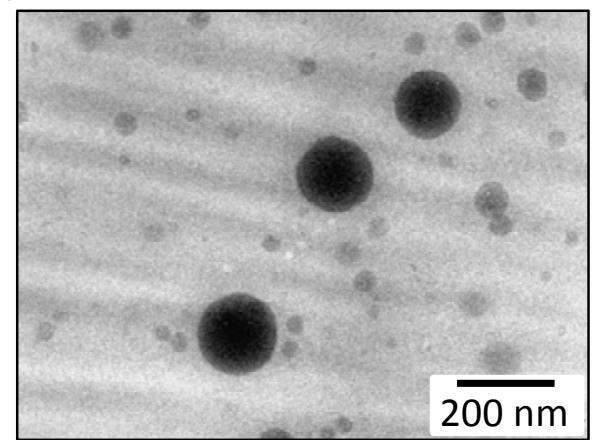

(b)

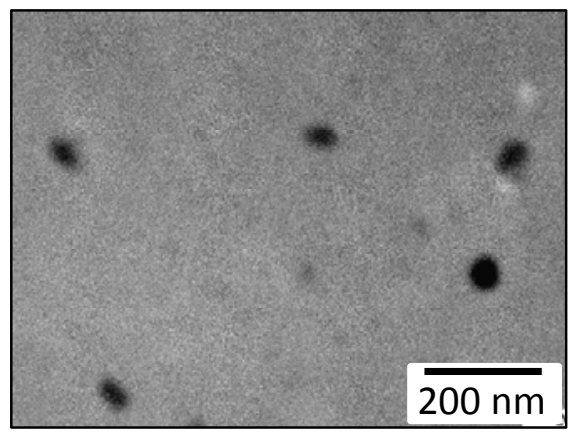

(d)

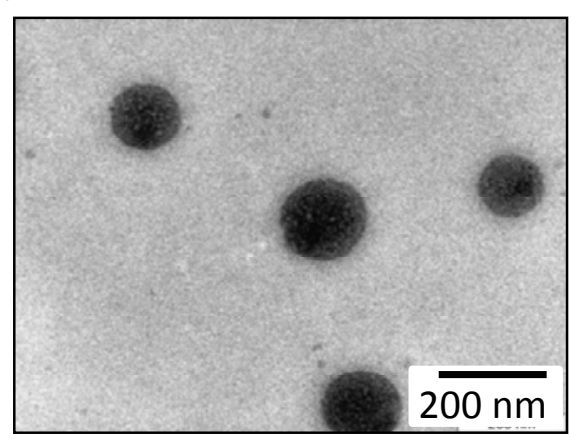

Figure 3. The representative TEM images of self-assemblies of $\mathbf{1 - \mathbf { C } _ { 1 4 }}$ (a) before and (b) after sonication, and those of $\mathbf{1}-\mathbf{C}_{\mathbf{5}}$ (c) before and (d) after sonication $(150 \mathrm{~W}, 38 \mathrm{kHz})$. 


\section{strumests small}
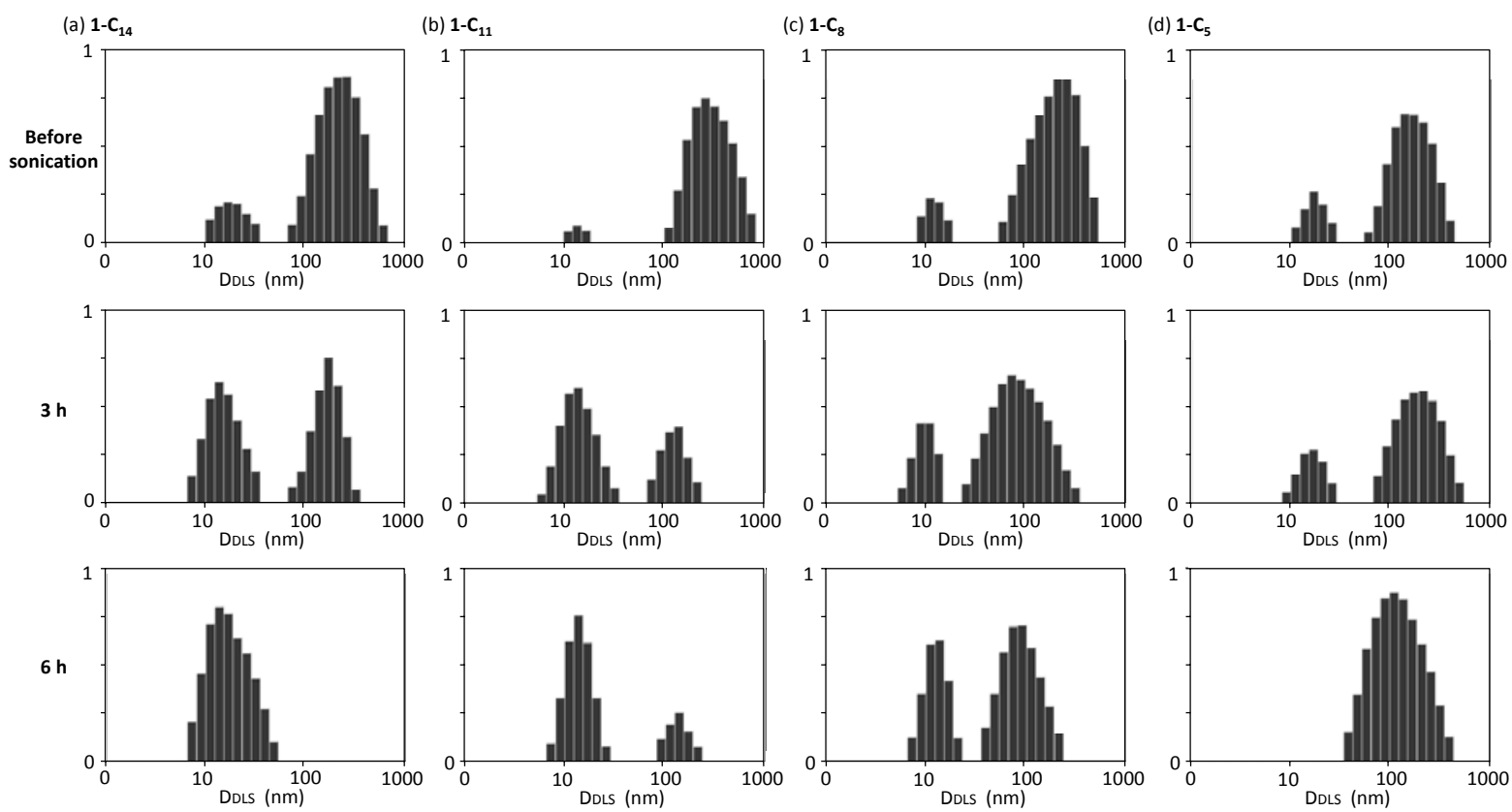

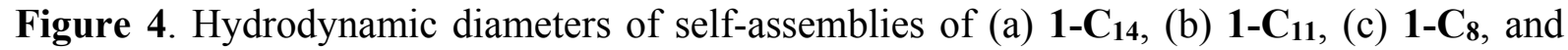
(d) $\mathbf{1}-\mathbf{C}_{5}$ in aqueous solution measured by DLS before and after sonication $(150 \mathrm{~W}, 38 \mathrm{kHz})$. 


\section{matom masoo \\ Submitted to}

(a)

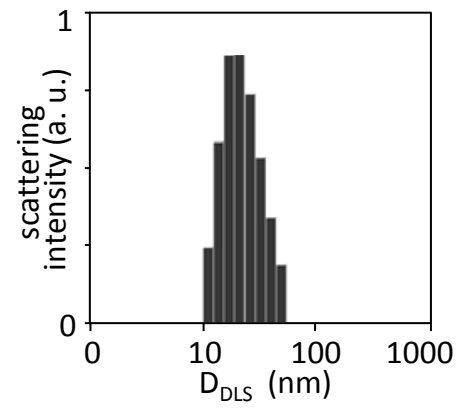

(b)

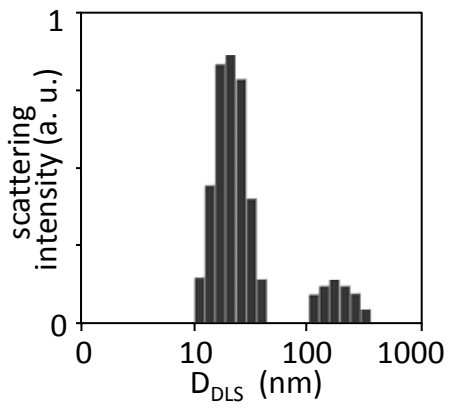

(c)

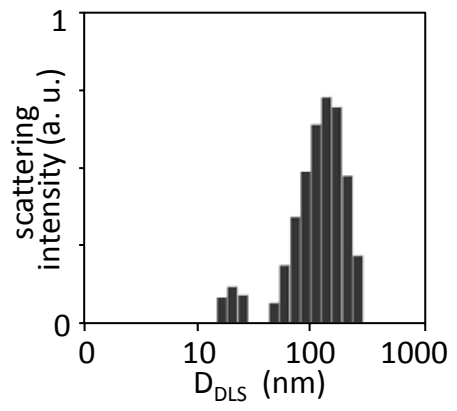

Figure 5. Hydrodynamic diameters of self-assemblies in aqueous solution measured by DLS. (a) 1C14, $24 \mathrm{~h}$ after sonication (diameter: $21 \pm 8 \mathrm{~nm}$ ), (b) 1-C14, $48 \mathrm{~h}$ after sonication (diameter: $19 \pm 6 \mathrm{~nm}$ and $168 \pm 54 \mathrm{~nm}$ ), and (c) 1-C5, $48 \mathrm{~h}$ after sonication (diameter: $19 \pm 3 \mathrm{~nm}$ and $123 \pm 48 \mathrm{~nm}$ ). 


\section{suminicats Small ${ }^{\text {numo }}$}

(a) $100 \mathrm{~W}, 28 \mathrm{kHz}$
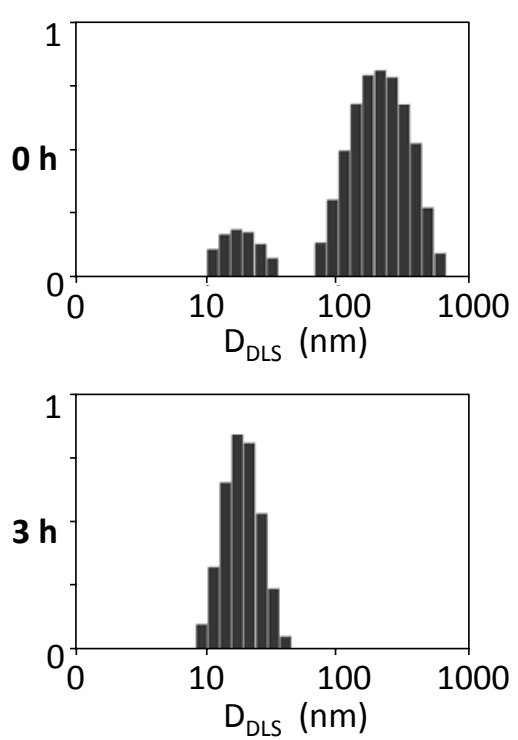

(b) $100 \mathrm{~W}, 45 \mathrm{kHz}$
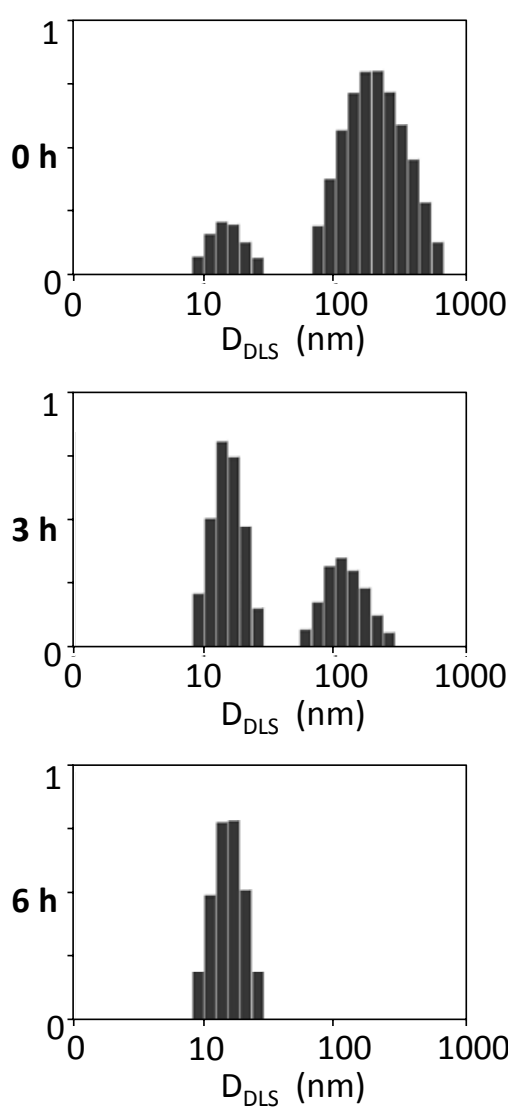

(c) $100 \mathrm{~W}, 100 \mathrm{kHz}$
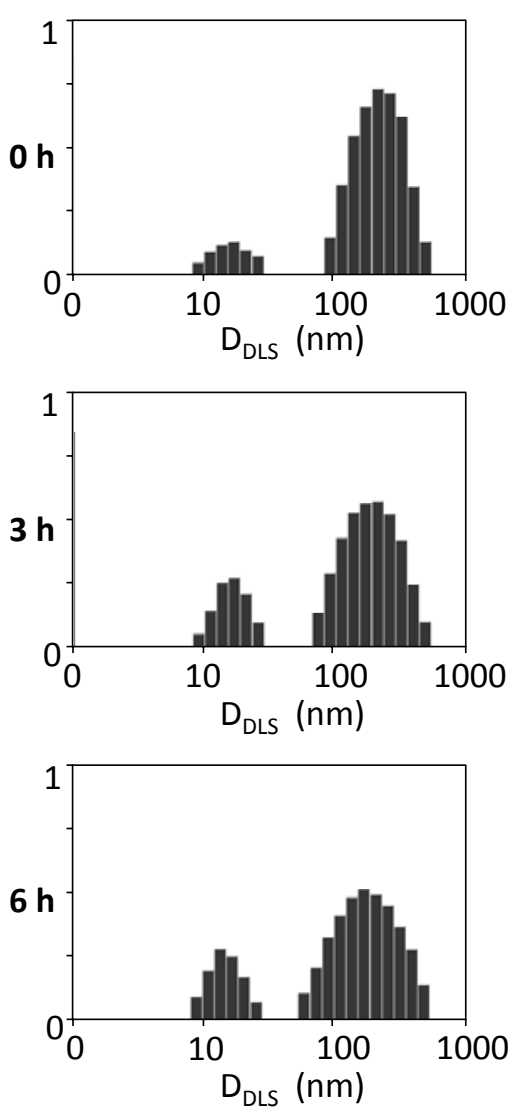

Figure 6. Hydrodynamic diameters (measured by DLS) of self-assemblies of $\mathbf{1 - \mathbf { C } _ { \mathbf { 1 4 } }}$ in aqueous solution after sonication with different frequencies. (a) $100 \mathrm{~W}, 28 \mathrm{kHz}$, (b) $100 \mathrm{~W}, 45 \mathrm{kHz}$, and (c) $100 \mathrm{~W}, 100 \mathrm{kHz}$. 


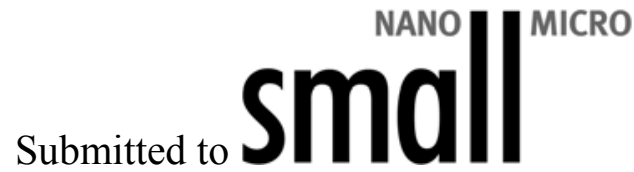

(a)

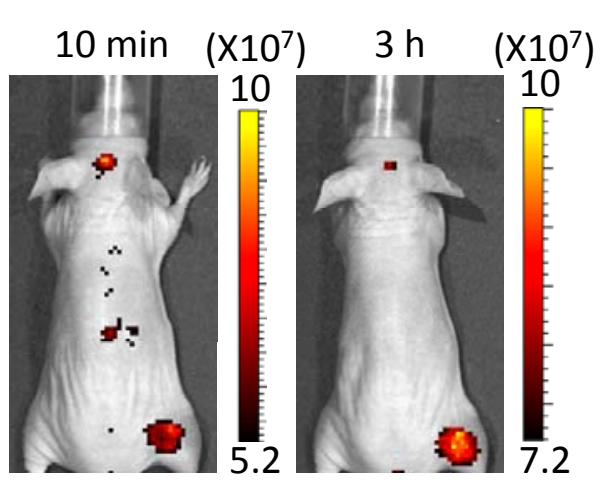

(b)

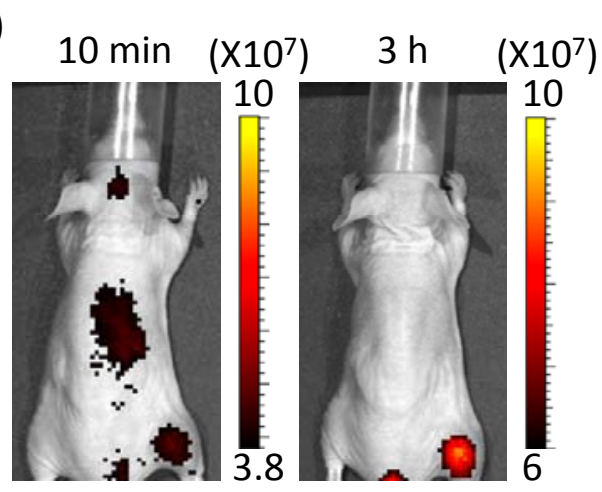

(c)

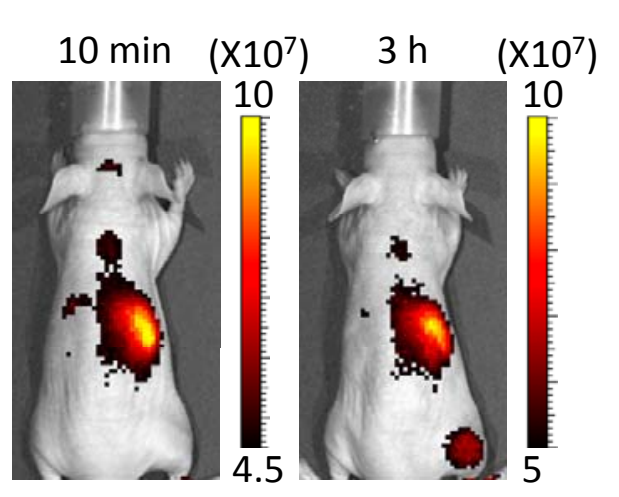

(d)

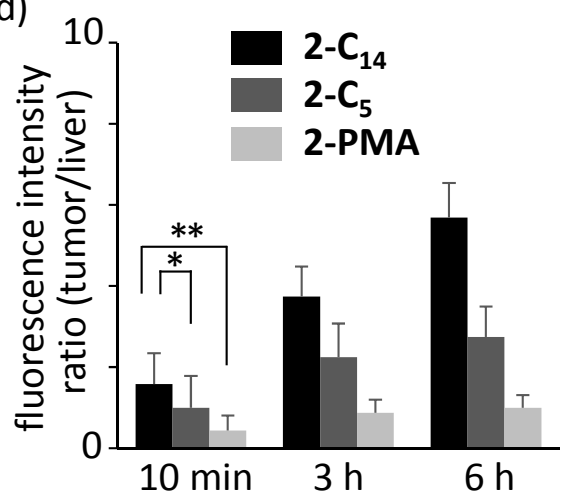

(e)
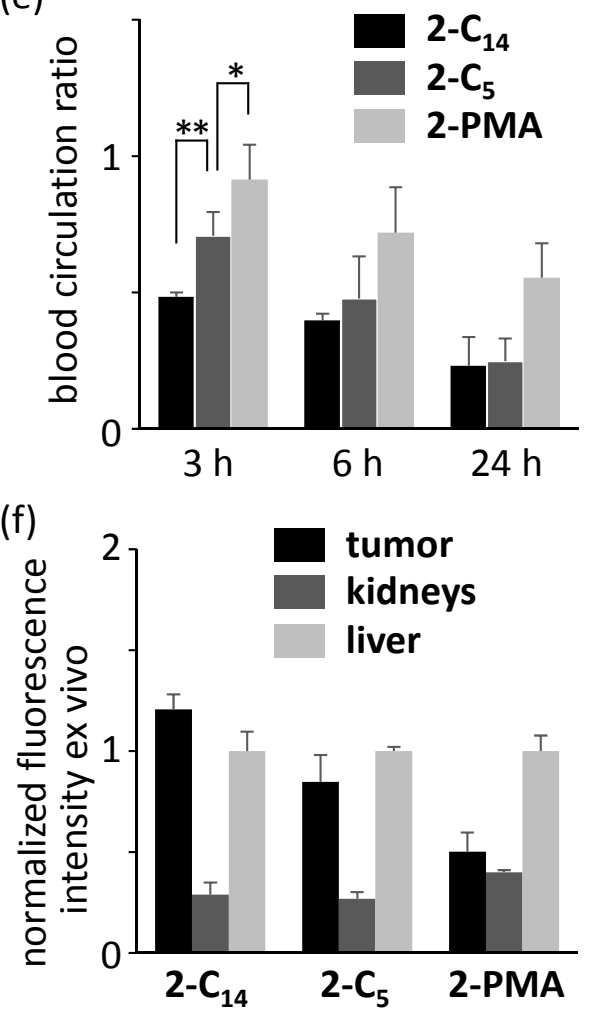

Figure 7. NIRF images (photons per second) of tumor-bearing mice after injection (after 10 min and $3 \mathrm{~h}$ ) of $100 \mu \mathrm{L}$ of ICG-containing polymers (a) $\mathbf{2}-\mathbf{C}_{\mathbf{1 4}}$, (b) $\mathbf{2}-\mathbf{C}_{\mathbf{5}}$, and (c) 2-PMA. Color code: low intensity black and high intensity yellow. Thresholds were appropriately established. (d) Fluorescence intensity ratios (tumor/liver) and (e) blood circulation ratios of 2-C $\mathbf{1 4}$ (black), 2-C $\mathbf{C}_{\mathbf{5}}$ (dark gray), and 2-PMA (pale gray). (f) Fluorescence intensities (photon $\mathrm{s}^{-1} \mathrm{~cm}^{-2}$ ) of dissected major organs, tumor (black), kidneys (dark gray), and liver (pale gray), of the tumor bearing mice, which are normalized by those of the liver, one day after

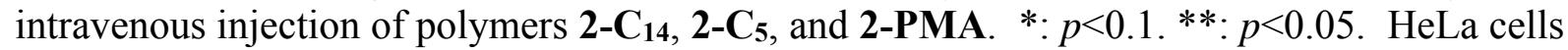
$\left(2 \times 10^{6}\right)$ was subcutaneously inoculated into the right hind leg of 6-week-old nude mice. 


\section{sumenstsmalll}

\begin{tabular}{|c|c|c|c|}
\hline monomer & $\mathrm{R}$ & monomer & $\mathrm{R}$ \\
\hline $3-\mathrm{H}$ & $\mathrm{H}$ & & \\
\hline $3-C_{5}$ & $\mathrm{OC}_{5} \mathrm{H}_{11}$ & 3-chol & \\
\hline $3-C_{8}$ & $\mathrm{OC}_{8} \mathrm{H}_{17}$ & & \\
\hline $3-b C_{8}$ & $\mathrm{OCH}_{2} \mathrm{CH}\left(\mathrm{C}_{2} \mathrm{H}_{5}\right) \mathrm{C}_{4} \mathrm{H}_{9}$ & & \\
\hline $3-C_{11}$ & $\mathrm{OC}_{11} \mathrm{H}_{23}$ & 3-PMA & \\
\hline $3-C_{14}$ & $\mathrm{OC}_{14} \mathrm{H}_{29}$ & & \\
\hline $3-C_{22}$ & $\mathrm{OC}_{22} \mathrm{H}_{45}$ & & \\
\hline
\end{tabular}

Figure 8. Norbornadiene monomers for ROMP. 


\section{NANO MICRO \\ Submitted to \\ small}

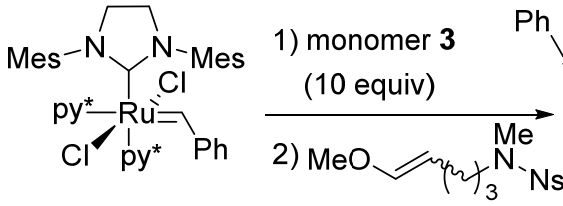

(20 equiv)

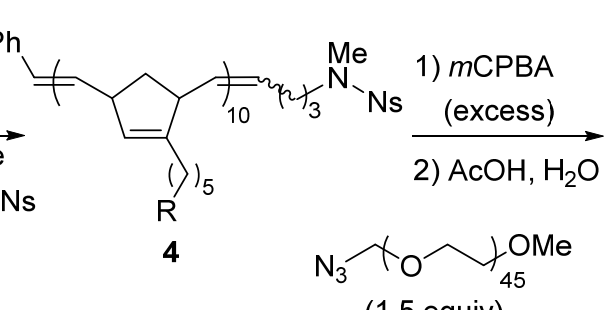

(1.5 equiv)
1) $\mathrm{NaH}$ (4 equiv) THF, $60^{\circ} \mathrm{C}, 17 \mathrm{~h}$

2)<smiles>CCC1=CCC(CCBr)C=C1</smiles>
(2 equiv)
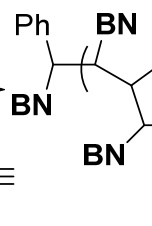

BN BN NMeNs Cul (0.1 equiv) $\mathrm{DBU}$ (0.1 equiv) DMF, $50^{\circ} \mathrm{C}, 15 \mathrm{~h}$

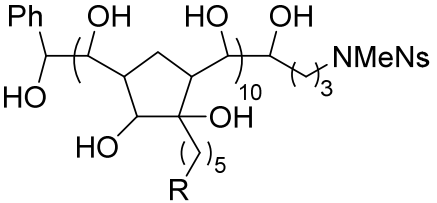

5

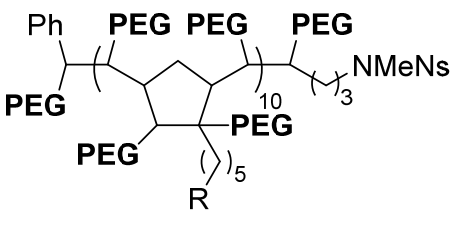

1

Figure 9. Synthesis of amphiphilic Janus-type polymers 1. 
subminicts Small
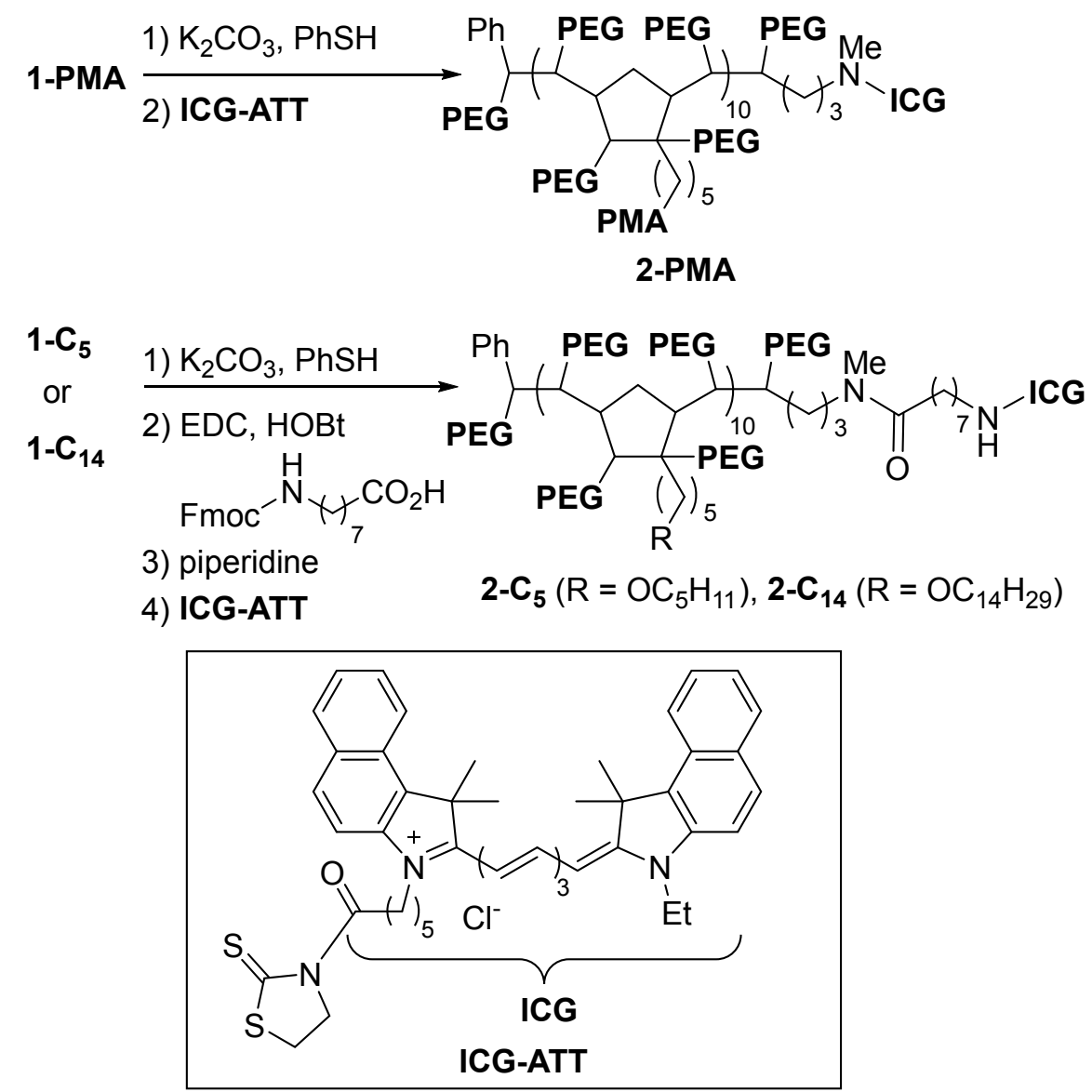

Figure 10. Synthesis of amphiphilic Janus-type polymers 2. 


\section{smallla}

Table 1. Diameters of self-assemblies of polymer 1.

\begin{tabular}{|c|c|c|c|}
\hline Polymer & $D_{D L S}(n m)$ before sonication ${ }^{[a]}$ & $D_{\text {DLS }}(\mathrm{nm})$ after sonication ${ }^{[a]}$ & $\mathrm{D}_{\text {TEM }}(\mathrm{nm})$ after sonication ${ }^{[\mathrm{b}]}$ \\
\hline $1-\mathrm{H}$ & $12 \pm 3,225 \pm 79$ & $198 \pm 134$ & $179 \pm 24$ \\
\hline $1-C_{5}$ & $16 \pm 4,158 \pm 69$ & $124 \pm 71$ & $110 \pm 16$ \\
\hline $1-C_{8}$ & $11 \pm 2,196 \pm 95$ & $12 \pm 3,86 \pm 37$ & $\_^{[c]}$ \\
\hline $1-\mathrm{bC}_{8}$ & $9 \pm 2,217 \pm 99$ & $263 \pm 167$ & $193 \pm 25$ \\
\hline $1-C_{11}$ & $13 \pm 2,290 \pm 135$ & $13 \pm 5,114 \pm 33$ & $-^{[c]}$ \\
\hline $1-C_{14}$ & $10 \pm 3,131 \pm 71$ & $18 \pm 5$ & $25 \pm 15$ \\
\hline $1-C_{22}$ & $21 \pm 7,135 \pm 74$ & $24 \pm 6$ & $27 \pm 16$ \\
\hline 1-chol & $20 \pm 7,195 \pm 86$ & $259 \pm 172$ & $196 \pm 22$ \\
\hline 1-PMA & $115 \pm 104$ & $90 \pm 66$ & $107 \pm 27$ \\
\hline
\end{tabular}

[a] Hydrodynamic diameters of self-assemblies in aqueous solution measured by DLS. [b] Distribution of diameters of self-assemblies determined by TEM. [c] Not determined. 
 \\ Submitted to \\ small}

Table 2. ICG-conjugated Janus-type polymers 2 and properties of their self-assemblies.

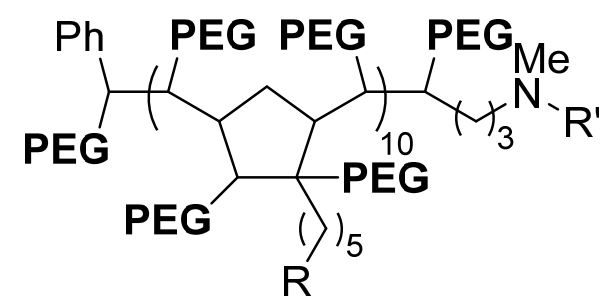

ICG-conjugated polymer 2

\begin{tabular}{|c|c|c|c|c|c|}
\hline \multicolumn{3}{|c|}{ lus-coirugated putyilel 2} & \multicolumn{3}{|c|}{ (112)5 } \\
\hline Polymer & $\mathrm{R}$ & $\mathrm{R}^{\prime}$ & $\mathrm{D}_{\mathrm{DLS}}(\mathrm{nm})^{[\mathrm{a}]}$ & $\mathrm{D}_{\text {TEM }}(\mathrm{nm})^{[\mathrm{b}]}$ & $\operatorname{cac}(g / L)^{[c]}$ \\
\hline $2-C_{5}$ & $\mathrm{OC}_{5} \mathrm{H}_{11}$ & $\mathrm{CO}\left(\mathrm{CH}_{2}\right)_{7} \mathrm{NH}-\mathrm{ICG}$ & $130 \pm 43$ & $116 \pm 22$ & $2.2 \times 10^{-4}$ \\
\hline $2-C_{14}$ & $\mathrm{OC}_{14} \mathrm{H}_{29}$ & $\mathrm{CO}\left(\mathrm{CH}_{2}\right)_{7} \mathrm{NH}-\mathrm{ICG}$ & $21 \pm 10$ & $25 \pm 17$ & $7.3 \times 10^{-4}$ \\
\hline 2-PMA & PMA & ICG & $170 \pm 77$ & $163 \pm 26$ & $3.5 \times 10^{-4}$ \\
\hline
\end{tabular}

[a] Hydrodynamic diameters of self-assemblies in aqueous solution measured by DLS. [b] Distribution of diameters of self-assemblies determined by TEM. [c] Measured by SLS. 


\section{smallla}

Table 3. ROMP-based polymers 4.

\begin{tabular}{|c|c|c|c|c|c|}
\hline Polymer & $\mathrm{R}$ & $\mathrm{MW}$ (theo) ${ }^{[\mathrm{a}]}$ & $M_{n}^{[b]}$ & $P D\left[^{[b]}\right.$ & Capping efficiency $(\%)^{[c]}$ \\
\hline $4-\mathrm{H}$ & $\mathrm{H}$ & 2000 & 2600 & 1.21 & 85 \\
\hline $4-C_{5}$ & $\mathrm{OC}_{5} \mathrm{H}_{11}$ & 2800 & 4800 & 1.27 & 89 \\
\hline $4-C_{8}$ & $\mathrm{OC}_{8} \mathrm{H}_{17}$ & 3300 & 3600 & 1.36 & 85 \\
\hline $4-\mathrm{bC}_{8}$ & $\mathrm{OC}_{8} \mathrm{H}_{17}$ & 3300 & 5500 & 1.16 & 90 \\
\hline $4-C_{11}$ & $\mathrm{OC}_{11} \mathrm{H}_{23}$ & 3700 & 3700 & 1.32 & 84 \\
\hline $4-C_{14}$ & $\mathrm{OC}_{14} \mathrm{H}_{29}$ & 4100 & 5800 & 1.10 & 83 \\
\hline $4-C_{22}$ & $\mathrm{OC}_{22} \mathrm{H}_{45}$ & 5200 & 5600 & 1.09 & 82 \\
\hline 4-chol & $\mathrm{OC}_{27} \mathrm{H}_{47}$ & 5900 & 3900 & 1.11 & 88 \\
\hline 4-PMA & PMA & 23000 & 18000 & 1.14 & 96 \\
\hline
\end{tabular}

[a] Theoretical molecular weight. [b] Determined by GPC. [c] Determined by ${ }^{1} \mathrm{H}$ NMR. 
Size-controlled self-assemblies of amphiphilic Janus-type polymers, which were synthesized via ROMP and $\mathrm{mPEG}$-grafting, were obtained by ultrasound irradiation. From in vivo optical tumor imaging, we found that large-size multimicellar aggregates with long blood circulation could slowly accumulate in tumor tissues. In contrast, the tumor site was clearly and rapidly visualized by small-size micelles.

\section{TOC Keyword}

K. Miki, * H. Hashimoto, T. Inoue, H. Matsuoka, H. Harada, M. Hiraoka, and K. Ohe*

Sonication-Induced Formation of Size-Controlled Self-Assemblies of Amphiphilic JanusType Polymers as Optical Tumor-Imaging Agents

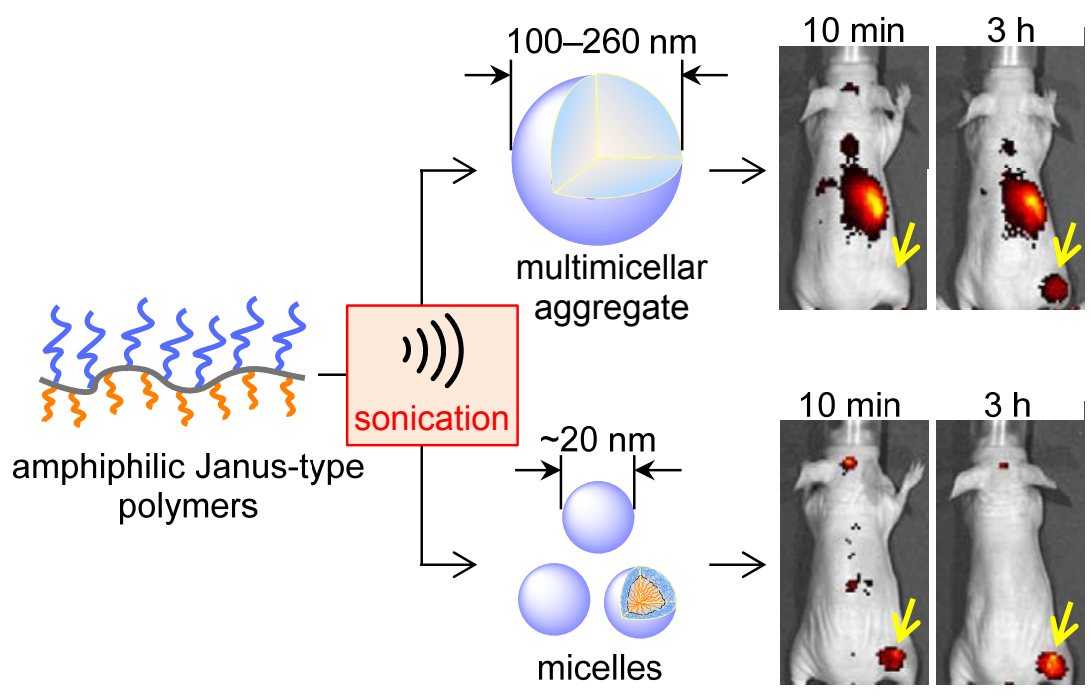

Page Headings

Left page: K. Miki et al.

Right page: Sonication-Induced Formation of Size-Controlled Assemblies for Tumor Imaging 